\title{
TALENT RECRUITMENT AND FIRM PERFORMANCE: THE BUSINESS OF MAJOR LEAGUE SPORTS
}

By

\author{
Daniel H. Weinberg \\ U.S. Census Bureau
}

CES 13-54

November, 2013

The research program of the Center for Economic Studies (CES) produces a wide range of economic analyses to improve the statistical programs of the U.S. Census Bureau. Many of these analyses take the form of CES research papers. The papers have not undergone the review accorded Census Bureau publications and no endorsement should be inferred. Any opinions and conclusions expressed herein are those of the author(s) and do not necessarily represent the views of the U.S. Census Bureau. All results have been reviewed to ensure that no confidential information is disclosed. Republication in whole or part must be cleared with the authors.

To obtain information about the series, see www.census.gov/ces or contact Fariha Kamal, Editor, Discussion Papers, U.S. Census Bureau, Center for Economic Studies 2K132B, 4600 Silver Hill Road, Washington, DC 20233, CES.Papers.List@census.gov. 


\title{
TALENT RECRUITMENT AND FIRM PERFORMANCE:
}

\section{THE BUSINESS OF MAJ OR LEAGUE SPORTS}

\author{
by \\ Daniel H. Weinberg \\ Senior Research Scientist \\ U.S. Census Bureau \\ daniel.h.weinberg@census.gov
}

3 October 2013

\begin{abstract}
Firms rely heavily on their investments in human capital to achieve profits. This research takes advantage of detailed information on worker performance and confidential information on firm revenue and operating costs to investigate the relationship between talent migration and firm profitability in major league sports. One key problem that firms have is identifying performance measures for its workforce, especially for potential employees (recruits). In contrast to nearly all other industries, in the industry of professional team sports, detailed information about the past performance of each individual worker (athlete) is known to all potential employers. First, I demonstrate using public data that worker (athlete) statistics aggregated to the establishment (team) level correlate with success on the field (measured in win percentage). Second, I use confidential data from the 2007 Economic Censuses, and from the 2007 and 2008 Service Annual Surveys to investigate the link between individual worker performance and team profitability, controlling for many other aspects of the sports business, specifically taking account of the mobility of athletic "stars" and "superstars" from one team to another. The investigations in this paper provide support for the hypothesis that hiring talented individuals (stars) will increase a firm's profit. However, there is not convincing support for the incremental benefit of hiring superstars. The mixed evidence suggests a benefit on balance.
\end{abstract}

\section{ACKNOWLEDGEMENTS}

Any opinions and conclusions expressed herein are those of the author and do not necessarily represent the views of the U.S. Census Bureau. All results have been reviewed to ensure that no confidential information is disclosed. The author wants to thank J ames Davis for his help in assembling the census and survey data for this study and Ron S. J armin, C.J . Krizan, Thomas A. Louis, and participants at a Census Bureau seminar for suggestions. 


\section{TALENT RECRUITMENT AND FIRM PERFORMANCE: THE BUSINESS OF MAJOR LEAGUE SPORTS}

\section{INTRODUCTION}

Firms rely heavily on their investments in human capital to achieve profits. This observation is more salient in service industries than in manufacturing since in the latter, investments in land, capital, and intermediate materials are very important to creation of the firm's physical output. This research will attempt to take advantage of detailed information on worker performance and confidential information on firm revenue and operating costs to investigate the relationship between talent migration and firm profitability. It is hoped that any insights gained from a focus on a specific industry wherein performance is relatively easy to measure can be useful in inferences about other industries.

One key problem that all firms have is performance measurement - identifying measurable outcomes for its workforce. In contrast to nearly all other industries, detailed information about the past performance of each individual worker (athlete) in the industry of professional team sports is known to all potential employers; indeed such statistics are publicized widely. Ichniowski and Preston (2012) have recently lamented the lack of research on the link between the data on player performance to revenue: "We have no information that allows us to calculate the relationship of these statistics to making the postseason or winning a championship, much less to marginal revenue effects of differences in these statistics through their effects on gate receipts or television contracts." [p.34]

Section 2 below summarizes the literature on both the relocation of talent (highperforming workers) from one firm to another, and the literature on the economics of professional sports teams. I focus on firms owning teams in the four major professional sports leagues in the United States: Major League Baseball (MLB), the National Basketball Association (NBA), the National Football League (NFL), and the National Hockey League (NHL). ${ }^{1}$ Section 3 discusses the data and their sources and presents the proposed empirical strategy. Section 4 describes the data I use - both public data on athletes and teams, and confidential microdata from the 2007 Economic Censuses, and from the 2007 and 2008 Service Annual Surveys on teams and the firms that own them. Section 5 presents the results and Section 6 my conclusions.

\footnotetext{
${ }^{1}$ Out of scope are the eight Canadian teams (one baseball, one basketball, and six hockey) as firm-specific data are not available for them.
} 


\section{LITERATURE REVIEW}

\subsection{The Effects of Talent Relocation}

The literature on the effects of talent relocation is sparse, mainly because of the aforementioned difficulty of accurately measuring worker performance. It fits into a relatively new sub-specialty of labor economics, specifically personnel economics (Lazear and Oyer 2007, Lazear and Shaw 2007, Oyer and Schaefer 2011) in that it focuses on (in Lazear and Oyer's words) "interactions between a firm and workers [that] explicitly or implicitly consider a firm trying to maximize some objective (usually profits)." [p. 2] The work is also related to organization (institutional) economics in that it is intended to illuminate how firms behave on the demand side of a labor market (Oyer and Schaefer 2010, p. 2).

Studies have attempted to measure worker performance in a variety of ways. For example, Lenzi (2009) uses patents to measure the productivity of Italian inventors in a study of the role of worker mobility on knowledge transfer for knowledge workers (e.g., scientists, researchers, inventors, technicians). Zucker et al. (2002) measure the performance of biologists as the number of genetic sequences discovered and the number of citations of their work. Shaw and Lazear (2008) measure the productivity of autoglass installers as the number of windshields installed per day.

The research on star performance can be traced to the seminal work of Rosen (1981) and Adler (1985). As characterized by Franck and Nüesch (2012), “Although Sherwin Rosen explains how small differences in talent can translate into large differences in earnings, Moshe Adler argues that superstars might even emerge among equally talented performers due to the positive network externalities of popularity." [p. 202] They go on to note that "In team sports, for example, superstars may have personal appeal or charisma, an element that attracts fan interest even after controlling for their contribution to the team's (increased) playing quality." [p. 204] They used press publicity as measured in the LexisNexis database as a measure of soccer star popularity, defining superstars (as did Rosen) as the players at the top end of the market value distribution.

Other studies of labor mobility include Ravid (1999) who used the number of Academy Awards and nominations received, as well as participation in top-grossing films, to identify stars; Gardner (2005), who studied talent mobility in the software industry, but did not attempt to quantify the role individual worker performance plays in labor mobility; and Groysberg et al. (2008) who studied security analysts using independent assessment of analysts to identify 
stars. ${ }^{2}$ An innovative study using matched employer-employee data by Andersson et al. (2009) concluded that "software firms that operate in product markets with highly skewed returns to innovation, or high variance payoffs, care more likely to attract and pay for star workers." [p. $34]^{3}$ Another recent study that exploited matched employer-employee data is Campbell et al. (2009). While their focus was on entrepreneurship efforts by employees in the legal services industry, they find different results for high and low performers, and thus suggest that attempts to distinguish among such workers is a fruitful line of inquiry. Other studies of star mobility include Krautmann and Oppenheimer (1994) and MacDonald and Reynolds (1994) who studied baseball.

Labor markets are not monolithic: "The extent to which matching, search, and asymmetric information are prevalent is likely to vary across labor markets." [Oyer and Schaefer 2011, p. 1785] The market for athletic labor is not typical. For the most part, potential employers have extensive information about the athletes' past performances, and on how those performances in a team environment contributed to maximizing their previous employer's intermediate objective (achieving a high ratio of wins to losses). Similarly, the worker knows a great deal about the firm's past employment practices, at least for the establishment (the team) for which the employer wants him to work. The unknowns involve the potential employee's ability to mesh with other workers in the work environment (the game) and with supervisory personnel (the team's manager), though word-of-mouth circulates relevant information about intangible aspects of both the worker's performance (e.g., 'Does he listen to the coaches?') and the team environment (e.g., 'Are team behavior rules strictly enforced?').

New prospective employers must also be wary. As Groysberg et al. (2008) note, "Firms may hire stars whose performance, divorced from its previous context, fails to meet expectations." [p. 1215] This could be both because the player who changes teams loses firmspecific human capital (e.g., their personal and professional interactions with their teammates such as the ability for the shortstop and second baseman in baseball to execute double plays in baseball) but also because the new firm (team) could offer lower-quality support (i.e., lesstalented teammates). Glenn et al. (2001) have shown that firm-specific human capital is important in baseball, with the value of trades varying by player position.

Nevertheless, with close-to-perfect information on both sides of the employer-employee relationship, it seems that the business of professional sports is a good venue to understand the

\footnotetext{
2 They use the trade journal Independent Investor "All-America Research Team." This measure was also used by Clarke et al. (2007).

3 They talk about the ability of star workers to "produce home-run innovations," an interesting sports analogy given the topic of my research.
} 
value of talent relocation. Yet a note of caution is called for. As Groysberg et al. (2008) note, "When a firm that possesses an informational advantage fails to make a counteroffer to keep the employee from leaving, the hiring firm is likely to suffer a winner's curse." [p. 1217] On the other hand, the acquiring firm may be able to take more advantage of externalities generated by the new employee than the old firm. For example, Yang and Shi (2011) note that while "the rise of a star athlete is accompanied by exceptional individual performance $[;$...] being in a good team and having good teammates help." [p. 353]

Another note of caution is that it is quite difficult to specify all the dynamics involved in a firm-athlete interaction. Each party wants to maximize their own "profit" from the transaction. The firm wants to maximize the discounted net present value of the future stream of revenues (from all sources) less costs. The player wants to maximize the discounted net present value of future salary and endorsements. Both calculations require a multi-year perspective, and neither perspective may be totally aligned with a team's objective (presumably winning a championship). For example, a player about to become a free agent might be interested in maximizing his individual statistics, even to the detriment of the team's overall performance.

\subsection{The Business of Sports}

Professional sports holds a unique place in American life. As Humphries and Howard (2008) note, "From one perspective, the sports industry is just another industry in a modern economy. The sports industry ... is a collection of firms producing an array of products and services that meet the demands of modern consumers. ... But from another perspective, the sports industry differs in profound ways from other industries. What other industry has an entire section devoted to it in most local newspapers across the country?" [p. vii]

Stewart and J ones (2010) note: "The essential premise of sports economics is that teams may be modeled as profit maximizing firms serving a demand for their product in their output market." [p. 488] ${ }^{4}$ Yet teams are not necessarily the entity to analyze for profit motives. As I view the situation, teams are establishments, often controlled by firms with other interests. Firms often own more than one team, manage arenas, and sell other services such as concessions, parking, and local broadcast rights. In some cases, they have their own cable networks. It is the revenue minus costs for the enterprise (firm) as a whole we need to examine, and if possible profit over multiple years, not just one year, as sports teams will invest in players and arenas for multiple years, hoping to reap rewards for early developmental investments. This perspective is echoed in the following quote from a team owner: "If you just looked at the

\footnotetext{
${ }^{4}$ Stewart and J ones argue that teams are actually multiproduct firms with two outputs - performance and
} entertainment. 
[Cleveland] Cavaliers in terms of revenues, profits and balance sheets ... people would say You're insane! You're nuts!' But if you look at all the tentacles, the impact on our other venues, it makes tremendous sense." [quoted in Gladwell 2011, endnote 1]

There are at least three recent studies of the impact of NBA stars on revenue (sales) Hausman and Leonard (1997), Berri et al. (2004), and Berri and Schmitt (2006). Hausman and Leonard analyze game attendance and conclude that "superstars are quite important for generating revenue, not only for their own teams but for other teams as well." [p. 586] They attribute this to factors beyond improvements in team quality: "The superstar may have a 'personal appeal' that attracts fans." [p. 591] Berri et al. temper Hausman and Leonard's conclusion a bit: "Although star power was found to be statistically significant, ... the ability of a team to generate wins appears to be the engine that drives consumer demand." [p. 45] ${ }^{5}$ MacDonald and Reynolds (1994) found that "the salaries of the very highest paid players in MLB disproportionately exceed their relative productivity advantage." [p. 444]

In analyzing the business of sports, one can start with the basic premise of a profitmaximizing firm hiring workers: "Each owner will bid up to the player's expected marginal revenue product. None of the owners know what the player's output will be, but each forms an expectation." (Zimbalist 2011, p. 12) ${ }^{6}$ Yet the labor market for professional sports athletes is not a free market. Leagues have formed because spectators want to witness contests between teams, and leagues can efficiently organize such contests. ${ }^{7}$ Rosner and Shropshire (2004) argue that

Leagues combine elements of cooperation and competition and allow independent team owners to seek monetary gains that might otherwise be unavailable if purchased unilaterally through the playing of disparate contests. Indeed, it is doubtful whether professional team sports could survive in the absence of leagues. Leagues offer an enticing, profit-maximizing structure to teams both on and off the playing field. Though professional sports teams are clearly competitors in the field, leagues benefit owners by providing regular and championship seasons of play and offering a unitary set of playing rules, both of which are designed to maximize fan interest and consequently, team profits. Off the field, competition among teams is generally limited to the pursuit of scarce playing and managerial talent. Professional sports leagues are cooperative endeavors away from the playing field, with teams jointly engaging in numerous practices that maximize the profits of the collective entity. [p. 21]

${ }^{5}$ However, Berri and Schmitt (2006) confirm the superstar externality that Hausman and Leonard found. ${ }^{6}$ See also Quirk and Fort 1992.

${ }^{7}$ Leagues have been around for quite some time. Kouvet (1977) noted: "In the ancient republic of Rome, ... the leading chariot drivers ... belonged to four teams. ... All four teams were organized into a league run by the four corporations. ... Almost two thousand years before Catfish Hunter got $\$ 3.75$ million for switching teams, an ex-slave named Diocles got 35 million sesterces ( $\$ 1.8$ million) for switching stables ... an income one hundred times that of the entire Roman Senate." 
Scully (1995) argues that "Teams must ...collude to some degree, if only to establish uniform playing rules, and establish a credible champion." [p. 28 $]^{8}$ U.S. leagues are different from most others in the world. ${ }^{9}$

Kahn (2000) argued that "Sports owners are a small and interconnected group, which suggests that they have some ability to bond together and act as monopsonists in paying players. The result is that player pay is held below marginal revenue product." Yet the players have countervailing power -- the limited supply of athletes with the requisite skills to play the sport at a high level conveys some bargaining power on the workers. ${ }^{10}$ Thus, leagues have placed numerous restrictions on player bargaining rights and mobility. Frick and Simmons (2008) illuminate these restrictions, which include a player draft, a reserve clause, free agency only after an initial period of employment, and a salary cap. ${ }^{11}$

It has been argued that consumers will lose interest, even in dominant "home" teams, if the contests are too lopsided. ${ }^{12}$ Thus, the leagues have introduced the above-noted restrictions to maintain "competitive balance", that is, to ensure that some equality of quality (and thus the competitiveness of each game) is maintained through the teams in the league.

Without limits, teams from [small markets] would stand little chance of attracting the best players because they cannot afford to pay salaries that match those offered by teams from [big markets]. This, in turn, would endanger competitive balance, as teams from large cities would regularly win more games and more championships than teams from small cities. A league that that lacks competitive balance would endanger teams from large and small cities

${ }^{8}$ Collusion among firms is per se illegal under existing antitrust laws. Professional sports have exemptions.

${ }^{9}$ In the U.S., membership in professional leagues is fixed (except for expansions and contractions). In the rest of the world, leagues have promotion and relegation - the strongest teams get promoted from lowerranking divisions to higher-ranked ones, replacing the poorest performers in those higher divisions (which are "relegated"-demoted). It is argued that this international system enhances fan support by making each division more competitive.

10 Worker-owner conflict is not new either. Kouvet (1977) also noted: "The increasing strife between players and owners is mirrored by Diocles' statement two millennia earlier: 'I do not care that I am exploited,' he said, "I exploit those that exploit me."' [cf. footnote 8]

11 "In North America these restrictions include:

- A player draft where initial entry into the league is through the organized recruitment of a pool of available players, usually from college;

- A reserve clause where players are tied to their teams until they qualify for free agency;

- A long period before free agency (the freedom to move to any club that makes a suitable salary offer) is achieved;

- A salary cap that imposes a ceiling on total payroll allowed for a team, usually as a percentage of designated revenues. ... Baseball does not have a salary cap and its primary tool for redistributing revenues is currently a luxury tax on high revenue teams." [Frick and Simmons 2008, p. 159]

12 Berri et al. (2004) note: "The theoretical literature argues competitive imbalance, or the on-the-field domination of one or a small number of organizations, reduces the level of uncertainty of outcome, and consequently reduces the level of consumer demand. The empirical literature ... has also generally confirmed a relationship between uncertainty of outcome or competitive balance and demand for tickets to sporting events [p. 33]." 
alike, as fans ultimately lose interest in games whose outcome is a foregone conclusion. Finally, ever-increasing payrolls drive up the cost of operation for all teams further endangering their financial status. [Frick and Simmons 2008, pp. 181-2] ${ }^{13}$

Krautmann and Oppenheimer (1994) reinforce the need for league restrictions.

New sources of revenue beyond ticket sales have become increasingly important, as Mason and Howard (2008) note. ${ }^{14}$ Key sources of revenue to the firms owning teams are premium seating (e.g., 'club seats'), personal seat licenses (the right to buy a season ticket), arena naming rights (e.g., 'Verizon Center'), media rights (broadcast, cable, local), new media (Internet, digital television, mobile phones), merchandising, sponsorships, expansion fees, parking, advertising, concessions and restaurants, facility tours and associate entertainment activities (e.g., museums), retail stores, and regional sports networks. ${ }^{15}$ Some teams even sell stock in their companies, albeit with limited voting power. ${ }^{16}$

Owning a firm with multiple lines of business can enhance profitability. As Rosner and Stropshire (2004) note “Viewing sports franchises as entertainment assets, corporations have attempted to use them to garner additional revenues through the team's playing facility and media rights. In theory, the ownership of the team and both its playing facility and programming rights allows the corporate owner to enhance its value through the exploitation of

13 Revenue sharing is also thought to improve competitive balance by "redistributing pivotal marginal players among teams." [Miller 2007, p. 62] Miller also argues that reducing the number of years it would take to become a free agent would also help competitive balance, by "[causing] some free agents to sign with low-revenue teams who otherwise would have signed with large-revenue teams. [p. 78]"

14 Mason and Howard further state: "While the [NHL]'s total gate receipts are the smallest among the four major leagues, NHL teams rely most heavily on ticket sales with on average about 41 percent of their total annual income derived from box office revenues. [MLB] and the NBA depend on over a third of their gross revenues from ticket sales, at 36 and 31 percent, respectively. Interestingly, the most prosperous of all the major leagues, the NFL, is the least dependent on ticket sales, which account for only 23 percent of the total revenues generated by NFL teams ... a result of the league's enormous popularity on television [p. 126]."

${ }^{15}$ For the merchandising aspect, "Licensees - the manufacturers of these products - typically pay the sports property a royalty of approximately $8.5 \%$ of the wholesale selling price of the goods in exchange for the right to sell products containing league and team names, logos, and marks. These monies are paid by the licensees to each league's properties division. The respective properties division then pools the funds and distributes them equally across all league teams, similar to the manner in which revenues generated from the sale of national media rights are apportioned." (Rosner and Shropshire 2004, p. 177)

${ }^{16}$ Stroz 2001 terms this "a 'victimless' crime, involving fans who are more than willing to part with hardearned dollars for the novelty and prestige of part ownership in a sports franchise and unscrupulous owners who are more than willing to accept their money." [p. 20]). The NFL Green Bay Packers were the first team to offer shares to the public, in 1923 (Stroz 2001) and they recently (2011-2012) advertised their fifth stock ownership sale, in order to pay for Lambeau Field renovations, but publically acknowledged the limited value of the shares. [ $<$ http:/ / packersowner.com/ faq>, accessed $6 \mathrm{~J}$ anuary 2012]. While other teams have at times been publically owned (e.g., the Boston Celtics), none are now except for the Packers. Public ownership likely prevents team relocation (Green Bay is the smallest media market in the four leagues). 
a wide range of synergies, including cross-promotional opportunities, the creation of additional distribution outlets, and higher visibility in the marketplace, as well as risk reduction and cost savings through economies of scale." [p. 2] This wider scope of activity can allow a firm to harness some of the synergies and bid higher for a player's contact than another firm in a smaller market or with fewer ancillary businesses. As Ichniowski and Preston (2012) note, “teams may receive especially large economic payoffs from identifying 'franchise players' around whom they can build championship caliber teams." [p. 35]

\section{THE ANALYSIS APPROACH}

The gaps in the existing literature are twofold. First, there are few studies that are able to convincingly measure worker performance and relate that to business outcomes. This may be important because if one views firms as profit-maximizing, the sports establishments which they manage may be given objective functions different than profit-maximization, due to externalities generated by workers in those establishments (athletes) for the enterprise as a whole. Second, no study has heretofore used data from teams in more than one sports league to provide insights into outcomes in the sports industry.

My analysis plan is as follows. First, I estimate a different model for each of the four major U.S. sports that demonstrates the relationship between average worker performance characteristics and success on the playing field, with the latter measured as the proportion of wins to games played in the regular season. ${ }^{17}$ The observations are at the establishment (team) level, with separate regressions for each of the four professional leagues under study. ${ }^{18}$ I use independent variables (which of course will vary by sport) measuring both offensive and defensive skills. Since the dependent variable is constrained to be between zero and one, I use a logit specification. Once these regressions have been estimated, I then regress the residuals from each equation on alternative measures of stardom and superstardom to see if these measures help explain any additional variation in winning percentage. I categorize players into three (admittedly arbitrary) categories: journeyman players, stars, and superstars.

\footnotetext{
${ }^{17}$ All data for those regressions have been obtained from public sources.

18 Major League Soccer is excluded both because of its recent origin (the first season was 1996) but also because all teams in the league are owned by one corporation. The Women's NBA is also excluded because of its recent origin (1997) and its ownership structure. Teams and the league were collectively owned by the NBA until the end of 2002, when the NBA sold WNBA teams either to their NBA counterparts in the same city or to independent organizations. World Team Tennis is excluded because of its fluctuating fortunes, complicating the development of lagged variables (it operated from 1974 to 1978 and was reestablished in 1981, fluctuating in size since then from 4 to 12 teams).
} 
Past researchers have used different methods to identify stars and superstars. These include selections to All-Star games (Hausman and Leonard 1997, Scott et al. 1985, Brown et al. 1991, Ichniowski and Preston 2012), All-Star votes (Berri et al. 2004, Yang and Shi 2011), and media designations (Burdekin and Idson 1991). I test four alternate combinations of definitions for stars and superstars - either restrictive or expansive for both - that involve league awards, all-star selections, and significant performance in selected skill areas (see Appendix B for a more detailed description.) The restrictive definition identifies 7 percent of players as stars (or superstars) and 3 percent as superstars; the expansive definition identifies 10 and 5 percent, respectively. Past performance is obviously not a perfect measure of future performance, but it plus judgment is the basis on which athletes are hired.

The second step is to estimate the effect of stars and superstars on firm (and team) profitability. I take two approaches - (1) estimation using two different definitions of profits (see below for the definitions and data sources) as a function of a number of independent variables (noted below) and a count of stars and superstars on the team (adjusting for mid-season trades), and (2) a 'difference of differences' approach that looks at the year-to-year change in profits as a team acquires or loses a star or a superstar. While the first can be estimated for all firms using data from the Economic Censuses; the latter can be estimated only for single-unit firms (that is, those with one Employer Identification Number) who are surveyed by the Service Annual Survey (SAS) in consecutive years.

One concern is the presence of endogeneity in that more highly profitable teams can afford to outbid other teams for stars. As described above, this is mitigated in part by the leagues themselves attempting to maintain competitive balance by imposing such strictures as "luxury taxes", payroll caps, etc. I adjust the profit measures for heterogeneity (see below).

Professional sports firms are classified into North American Industry Classification System (NAICS) code 711211 (Sports teams and clubs), as businesses "primarily engaged in participating in live sporting events, such as baseball, basketball, football, hockey, soccer, and jai alai games, before a paying audience." In 2007, there were 750 firms operating professional sports teams or clubs, up from 621 in 2002 and 453 in 1997. Industry 711211 thus includes firms without franchises in the four sports leagues included in this study. Since worker performance in those other sports will not be measured in this study, I exclude those firms from the regression analysis.

Based on review of the literature, I hypothesize that profit is a function of the following factors, cumulated over all teams owned by the firm when applicable: 
- Team won/loss record, including lagged values, and playoff appearances and league championships in the previous 2 years (better past performance leading to more season ticket sales, higher attendance, and greater profits); ${ }^{19}$

- Number of playoff games played that year (leading to more gate revenue and higher profits);

- If a firm owns a team in more than one league (no one firm may own more than one team per league), and which leagues the teams are in; ${ }^{20}$

- How the arena was financed (specifically, were public funds used); ${ }^{21}$

- When the arena was built or substantially renovated (a proxy for fan amenities and the opportunity for owner profit such as through luxury suites, with younger age likely leading to higher profits);

- Whether the firm engages in non-sports businesses, measured by whether the firm has more than one establishment;

- Market size, measured as metropolitan area population and per capita personal income, with a larger and richer fan base likely leading to higher profits; ${ }^{22}$

- Whether there is competition for fans, measured by whether there is another team in the same metropolitan area in the same league; ${ }^{23}$

- Recent material change of ownership in the past 3 years;

- Change in on-field management in the past 3 years;

- Bankruptcy or league takeover of the team, franchise relocation, or league entry in the past 5 years; ${ }^{24}$

- Lockouts or strikes in the past 5 years; 25

- Presence and number of "stars" and "superstars", and possibly the flow of stars, not just the stock.

${ }^{19}$ Contemporaneous and 1-year lags are used; 2- and 3-year lagged winning percentages added no explanatory power.

20 As noted earlier in the text, reliance on teammates can help determine the success of a star, and since player interaction varies by sport, the league could well affect the profitability of the firm, as would other characteristics of the sport. Berman et al. (2002) assessed the level of interaction among players on MLB, NBA, and NFL teams, putting the NBA highest, followed by the NFL and then MLB. Using their criteria, I would place the NHL second in the list. Because the interaction needed for player success varies by sport, one would expect the sport involved to affect the outcome. Also, MLB has substantial expenses for minor league player development. As Zimbalist (2011, p. 95) notes "When comparing [labor costs as a percentage of revenue], it is necessary to make at least one important adjustment. MLB teams have to cover very substantial minor league player costs, while the NBA ... and the NHL ... have modest minor league player costs, and the NFL has none." Owning multiple teams could affect profitability in that the teams could share facilities (such as the playing arena).

${ }^{21}$ The extent of public financing varies greatly across teams. The complexity of arrangements and the inaccessibility of complete documentation precluded the specification of a more complex variable indicating the extent of public versus private financing or the allocation of revenue for ticket sales, concessions, and the like.

22 MacDonald and Reynolds (1994) used metropolitan area total personal income. I include both per capita income and population as independent variables.

${ }^{23}$ The presence of sports teams in the same metropolitan area in other leagues did not affect profits in exploratory regression estimates.

24 These three variables were included in exploratory regressions and had no effect on profits; further they serve to uniquely identify just a few teams and so are excluded from the regressions to improve disclosure avoidance.

25 Since there was a lockout for the entire 2004-2005 NHL season, the NHL dummy variable will capture any effects of that lockout so no separate variable was included. 
Similarly, change in profit from one year to the next may also be related to changes in some variables, but is possibly also related to the acquisition or loss of stars and superstars between or during those years.

\section{DESCRIPTION OF THE DATA}

The 2007 Census of Services (CS) has measures of employment, revenue (sales), and total annual payroll, but not other expenses. ${ }^{26}$ Some recent studies using CS microdata include Dunne et al. (2007) on dentistry and chiropractic services, Garicano and Hubbard (2009) on law firm specialization, Silk and King (2009) on the advertising and marketing services industry, Carnahan et al. (2010) on mobility in the legal services industry, and Limehouse and McCormick (2011) on law firm location. Microdata from the other Economic Censuses are available for firms with establishments outside the service sector. ${ }^{27}$ For the 109 firms with establishments in industry 711211, profit will be defined using CS data as the sum of revenue minus labor cost, or Non-Labor Surplus (NLS) for all establishments that are part of the firm. These regressions will also be carried out for the 105 teams for which it was possible to identify their individual microdata.

Microdata from the Service Annual Survey (SAS) are not as widely used (Silk and King 2009 is the sole recent reference) but have the distinct advantage of allowing the researcher to define profit as operating revenue minus operating expenses, including payroll, rather than as operating revenue minus payroll alone, coupled with the disadvantages of a smaller sample size and no measure of employment. NLS is measured using 2007 SAS data in an attempt to replicate CS results, and for 2008, and then the broader measure of profit is estimated for the same years, and in a difference equation (change in profit from 2007 to 2008). ${ }^{28}$ There were 30 teams in the $2007 \mathrm{CS}$ and the 2007 and 2008 SAS. ${ }^{29}$

\footnotetext{
${ }^{26}$ For the Economic Censuses and annual economic surveys, reported values, tax records, past reports, and expert judgment are all used by Census Bureau analysts to edit the microdata and impute missing values in the file. The rate of imputation is low. For teams, in the sample, the imputation rates for sales, annual payroll, and employment are 10.2, 11.1, and 13.0 percent, respectively.

27 The microdata from the Economic Censuses and business surveys such as the Service Annual Survey are available on a restricted basis at the Census Bureau Research Data Centers.

${ }^{28}$ I attempted to create a third measure of profit by matching in data on depreciation/amortization from the 2007 Annual Capital Expenditures Survey (ACES). Too few firms in the ACES were also in the SAS sample to proceed.

29 Since the SAS is a survey of service industries, I could not get survey information on non-service sector establishments in all the firms, so the analysis of SAS data focuses on team-level data.
} 
Since the regressions might be skewed by the presence of both small and large firms, I normalize the profit measures in two ways: NLS or profit per employee, and NLS or profit as a percentage of revenue. ${ }^{30}$ The latter is estimated as a logit specification since it is limited to the $[-1,1]$ interval.

\section{RESULTS}

\subsection{Team Performance}

If team characteristics that measure average player performance have a relationship with winning, then one would expect that the more games a team plays, the less randomness will affect outcomes, and therefore the better the fit. MLB teams play 162 regular season games per year, the NBA and NHL play 81 regular season games per season, and the NFL plays only 16 regular season games. Thus one might expect a better fit for baseball versus basketball and hockey, and the latter two versus football. On the other hand, the specialization of the players to the tasks at hand might make it more difficult to measure average team performance. Football is the most specialized team sport, with players swapping in and out frequently and specializing in certain skills (e.g., kicking, pass protection), followed by baseball (with the key differences being their role in defense - differing by the nine player positions), then hockey (with goalies, defensemen, centers, and forwards playing different roles). Basketball is the least specialized with all players (centers, guards, and forwards) expected to perform both scoring and defensive roles. This complicates trying to predict the goodness-of-fit. Another complicating factor is the variety of performance statistics computed for each team and made available on the relevant web sites. The fewer the statistics available, the poorer the likely fit (the NHL had the fewest such statistics).

The first set of regressions uses the logit of the win percentage ( $\log \{w p /[1-w p]\}$ where $w p$ is the win percentage) as the dependent variable on a large set of team statistics obtained from each league's web site or fan sites. Collinearity is ignored as the main purpose is to explain as much of the variation in the dependent variable as possible. ${ }^{31}$ The results are summarized in Table 1. As mentioned above, one reason that the lowest explanatory power of team statistics on winning percentage $\left(R^{2}=0.6310\right)$ is for the NFL is because they play the fewest games in the regular season and there is less chance for random events to even out. The highest is for the NBA $\left(R^{2}=0.9777\right)$ followed by MLB $\left(R^{2}=0.9168\right)$ and then the NHL $\left(R^{2}=0.8295\right)$. The next

\footnotetext{
30 Since SAS does not collect employment data, CS employment is used for normalization of the SASbased NLS and profit measures.

31 I attempted to include a variable indicating change in head coaches in the current or previous 3 years, and an alternative showing the number of such transitions. Both variables had a t-statistic close to zero and were consequently omitted.
} 
step was to regress the residuals from the winning percentage regression on the measures of stardom. These results are shown in Table 2. For three of the leagues and for the pooled regression, the restrictive definition of stardom coupled with the restrictive definition of superstardom had the highest explanatory power (the NHL is the exception). That combination will be the default for reports on the profit regressions below, with other results noted as relevant.

5.2 Background Information

The Standard Statistical Establishment List was used to determine that the 109 firms that owned the 114 U.S. teams had 1,962 establishments in 2007. Of these, there are no data available at the Census Bureau for three agricultural establishments. Table 3 shows the distribution of the remaining 1,959 establishments by firm. There were only three very large firms (with more than 100 establishments), and 66 of the 109 firms had only one establishment. This distribution was used to create a multi-establishment dummy variable. ${ }^{32}$ Note that it is only the large firms with more than 20 establishments that operate in more than 5 two-digit NAICS sectors on average (of 17); many multi-establishment firms operate in just a small number.

Table 4 shows the summary statistics for the two untransformed dependent variables, for the CS sample of 109 firms, for the CS sample of 105 teams, and for the SAS sample of 30 teams. Firms with at least one sports team had average revenue of $\$ 631$ million but median revenue of only $\$ 177$ million (results of the skewed distribution shown in Table 3). Their non-labor surplus (NLS) was 38 percent of sales, and NLS per employee was $\$ 216$ thousand. When the sample is restricted to teams, sales are naturally on average lower, but there is reasonable agreement between the CS estimates for the 105-team CS sample and the estimates for the 30-team (SAS) sample ( \$156 million and \$159 million in average sales, respectively; \$155 and \$163 million for median sales). ${ }^{33}$ Mean and median NLS as percent of sales also match closely, as does NLS per employee. Sales estimates from the SAS for the SAS sample are slightly lower than for the same

\footnotetext{
32 Multi-establishment firms include both multi-unit firms (that is, firms reporting data for more than one Employer Identification Number) and single-unit firms that have more than one establishment.

33 USA Today publishes an estimated player payroll for all teams in the sample but one (see, for example, $<\mathrm{http}$ :// content.usatoday.com/ sportsdata/ football/ nfl/ salaries/ team>). For the 104 teams identified, the mean ratio of USA Today estimated player payroll to Census of Services annual payroll was 0.75 with a relatively low standard deviation of 0.25 . However, there were five teams for which the estimated payroll exceeded the CS payroll. This discrepancy can be result of many factors, among them one noted for NFL players: "contracts are not guaranteed and [the player] may not have received the entire amount" specified in his contract, and the more general comment that "Total team payrolls can also fluctuate significantly from year to year, depending on how a team accounts for its players' base salaries, bonuses, etc." When the regressions reported below were estimated for the 100 teams whose CS annual payroll did not exceed the USA Today estimated payroll, there were fewer coefficients statistically different from zero for regression for the ratio of NLS to sales, but there was no effect on the significance of the coefficients for NLS per employee. No coefficient was significantly different between the regressions for the 100-team and the 105-team samples.
} 
firms from the CS but are reasonably close ( $\$ 151$ million versus $\$ 159$ million at the mean and \$154 million versus \$163 million at the median, for the CS and SAS data respectively; labor costs are close). In contrast, profit for these teams in the SAS sample is widely variable and negative on average (recall that some firms may accept negative profits for their teams if other firmowned establishments benefit), but profits improve between 2007 and 2008.

Section 3 described the variables I hypothesized might affect profit. I obtained information for all the independent variables from public records; the ones included in the estimation are shown in Appendix Table A-1, which includes summary statistics for 2007 and 2008 for these variables and the variables that characterize stars and superstars for the full sample of 114 U.S. teams. ${ }^{34}$ There are no particular surprises in these data (for example, the average team wins half its games). ${ }^{35}$ The average team played in 3.4 playoff games in 2007, but the range was from 0 to 26; more games presumably means more profit. The average team plays in an arena that is 15 years old, and 75 percent of stadiums and arenas are publically financed. In 2007, 13 percent of sports team had had a change of ownership in the previous 3 years.

Using the restrictive definition for stars and superstars, one finds that the typical team had 2.7 stars and 1.1 superstars in 2007, though the former ranged from 0 to 8 , and the latter from 0 to 5 . There is not a lot of mobility from team to team, with an average team gaining or losing 0.4 stars pre-season and 0.05 stars mid-season (the figures for superstars are even lower of course, at 0.2 and 0.03 , respectively). Even though this lack of mobility might make it difficult to find significant results for the flow variables, the regressions with only stock variables (number of starts and superstars) explained a significant fraction of the variance in NLS only for one team-level regression (and no firm-level regression). Once the flow variables are included, all four regressions explain a significant fraction of the variance; thus, the regressions described below contain both stock and flow stardom variables.

\subsection{Effect of Stardom on Profitability}

Presented first are the NLS regressions for the full sample of 109 firms. Then I discuss the results for the team-level NLS regressions for the pooled sample. This is followed by a discussion of the SAS sample results for the NLS measure, and then for the profit measure.

\footnotetext{
${ }^{34}$ For the five pairs of teams owned by firms, new variables are constructed for the firm regressions that sum or average the data across the teams as appropriate.

35 Deviations from 0.5 for the win percentage, and the reason the in- and out-migration data do not match precisely in Table A-1, are due to the absence of Canadian teams from this table.
} 
Table 5 presents the results for the firm-level regressions using the Economic Census data. ${ }^{36}$ Even though none of the non-stardom characteristics had an independent significant effect on either measure of firm profit, it is reassuring that the $\mathrm{R}^{2}$ is reasonably high ( 0.36 and 0.35). Multi-establishment firms do have higher NLS per employee and as a percent of sales than do single-establishment firms (significant in one of the two regressions). A number of measures of stardom do significantly affect NLS. Stars acquired pre-season increase both NLS per employee and NLS as a percent of sales, and stars lost mid-season reduces NLS (the latter significant only for NLS per employee). There are some unexpected results for superstars at the firm level, however. ${ }^{37}$ The number of superstars acquired (lost) pre-season reduces (increases) both NLS measures (the opposite of expectations). This is not the result of teams shedding their roster of stars in favor of superstars, however.

Table 6 presents the results for the team-level regressions using the CS data. ${ }^{38}$ Some team-level independent variables now have some effect on NLS. NFL teams make higher profit than any of the other leagues, with the hierarchy of NLS being NFL (highest NLS), MLB, NBA, NHL (lowest). ${ }^{39}$ While not necessarily significant in all regressions, this is the common pattern. If a team is part of a firm that owns more than one team, NLS per employee is higher (but not NLS as a percent of sales). The number of stars increases both measures of NLS, but the number of superstars decreases NLS (the former significant only for NLS as a percent of sales). However, the number of superstars acquired pre-season increases both measures of NLS. 40

Table 7 presents the marginal effects of selected stardom variables for the 109 firms and the 105 teams. As noted earlier, adding a star pre-season adds to firm-level NLS -- \$192 thousand to NLS per employee, and 13 percentage points to NLS as a percent of sales. Also as

\footnotetext{
36 The restrictive-restrictive definition of stardom has the best fit and the highest number of significant stardom variables.

${ }^{37}$ The variable Number of stars counts superstars, so the variables involving superstars measure their incremental value.

38 The restrictive-restrictive definition of stardom has the same fit as the restrictive-expansive definition for NLS per employee and the same fit as the expansive-restrictive definition for NLS as a percent of sales, but has more significant stardom variables.

39 The differences between the leagues are all significant in the NLS per employee regression. In the NLS as percent of sales regression, the NFL and the MLB dummy variables are not significantly different, and the MLB and the NBA dummy variables are not significantly different. However, the magnitudes reflect the hierarchy described. One reason that NFL profits are higher may be that player contracts are not guaranteed that is, no salary is due if a player is released.

40 Since the level of NLS clearly depends on the league, the CS regressions were estimated separately for each league. The most consistent findings were that both the number of stars and the number of superstars acquired pre-season increases NLS (each significant in four of the eight regressions). Several stardom variables were omitted from those regressions because of multicollinearity, but additional variables had to be omitted in the NHL regressions due to their much sampler sample size (six of the eight Canadian teams excluded from the study are hockey teams).
} 
noted, adding a superstar pre-season or mid-season reduces firm-level NLS and losing a superstar increases NLS. Adding one superstar pre-season or mid-season reduces NLS per employee by $\$ 78$ thousand and \$348 thousand, respectively, and reduces NLS as a percent of sales by 11 and 37 percentage points, respectively. Similarly, losing a superstar increases both NLS per employee and NLS as a percent of sales at the firm level, both pre-season and midseason, by \$349-364 thousand, and 22-24 percentage points. (Note that all these are 1-year effects and may not persist. That is, longer-term changes in NLS could be different.)

Focusing on the 30 teams represented in the Service Annual Survey data, only one stardom variable affects either NLS per employee or NLS as a percent of sales for 2007 or 2008 (the number of superstars acquired mid-season reduces NLS as a percent of sales in 2008). Table 8 presents the results for the team-level regressions for the two profit measures, only available from the SAS data. The number of stars lost pre-season reduces profit per employee and profit as a percent of sales in 2008. Only one variable is significant in the 2007 regressions, so I will focus on the 2008 regressions, reminding the reader that the 30 teams in the SAS may not be representative of all 114 U.S. professional sports teams.

Teams that are part of multi-establishment firms have lower profits. MLB teams seem to have the highest profit (though not significantly more than NFL at the 0.10 level), but more than NBA or NHL teams. NBA teams seem to have the lowest profits, though not significantly less than the NHL teams at the 0.10 level). A higher winning percentage, more playoff games, and a higher MSA per capita income increases profit; previous success (having made the playoffs in the previous 2 years), a change in ownership in the previous 3 years, and having the arena financed publically all reduce profit. Turing to the stardom variables, the number of stars lost pre-season reduces profit per employee, and the number of stars lost mid-season increases profit per employee, the latter perhaps validating the hypothesis that teams out of contention for the championship will trade away higher-paid stars, such as those nearing free agency.

Table 9 examines the change in NLS and profit from 2007 to 2008, using a reduced set of independent variables that focus on change. Increases in the number of playoff games increases both NLS and profit per employee. The only stardom measure significant in two regressions was the number of superstars lost pre-season, which reduces the increase in NLS and profit as a percent of sales from 2007 to 2008. Losing one superstar pre-season reduces the increase in NLS as a percent of sales by 17 percentage points, and profit as a percentage of sales by 5 percentage points. 


\section{CONCLUSIONS}

The investigations in this paper provide support for the hypothesis that hiring talented individuals (stars) will increase a firm's profit. However, there is not convincing support for the incremental benefit of hiring superstars. The mixed evidence suggests a benefit on balance.

At the firm level, the number of stars acquired pre-season increases both non-labor surplus (sales minus annual payroll, or NLS) per employee and NLS as a percent of sales, and the number of stars lost mid-season reduces both NLS measures. At the sample means of sales and employees, this means an 1-year increase in NLS of between \$81 and \$324 million from adding a star and a loss of between $\$ 16$ and \$22 million from losing a star. Obviously, the latter is more precisely estimated. A puzzling result was found for superstars at the firm level however. The number of superstars acquired (lost) pre-season reduces (increases) both NLS measures (the opposite of expectations).

At the team level, the number of stars increases both measures of NLS. However, the number of superstars acquired pre-season increases both measures of NLS for teams (by between $\$ 7$ million and $\$ 35$ million per star, at the mean). The number of superstars decreases NLS (significantly only for NLS as a percent of sales), and also does so in the league-level regressions.

A much smaller sample was used to examine the change in profits (sales minus operating expenses) from 2007 to 2008. In those regressions, the number of superstars lost pre-season reduces the increase in NLS and profit as a percent of sales from 2007 to 2008 (by \$25 million and \$7 million, respectively, at the mean).

The robustness of the findings could be supported by repeating the analysis using many more years of data; that research is theoretically possible at least as far back as the 1997 Economic Censuses (the first coded into the NAICS classification system), and also including 2002 and 2012. The major constraint is the availability of team and player statistics as independent variables. While in principle available on the major sports websites, these data are difficult to access and download in bulk. ${ }^{41}$ The data preparation of team and player statistics for just the 4 years covered by the study took several weeks of detailed work. Unfortunately, data resellers charge substantial amounts (I was quoted "six figures"), making further historical analysis impracticable.

Another robustness check would be to repeat the analysis taking account of the multiyear nature of player contracts. Firms might hire superstars without the expectation of an immediate

41 The NBA does not provide sufficient team and player historical statistics on its web site; instead I used a download file from www.databasebasketball.com that starts in 1946. As of 2012, MLB provides annual statistics back to 1876, the NFL back to 1932, and the NHL back to 1997-1998. 
return, but rather a stream of additional revenue over several years. Further, since success in these sports leagues requires complementary players, it might take some time to acquire the players needed to complement the superstars' skills. It would be possible to cumulate revenue, sales, and non-labor operating expenses over several years of the Service Annual Survey to examine this alternative, albeit for a small sample of teams (not firms), reducing the generalizability of a multiyear study.

Is this result - that firms can make extra profits by hiring stars (and perhaps superstars) - broadly applicable to other industries? It almost goes without saying that it is worth hiring a "star" worker if the business owner can pay that worker less than his or her marginal revenue product (MRP). But it is perhaps the institutional constraints on entry (the player draft) and free agency in major league sports that permit such firms to make extra profit beyond the MRP. So pending further research applying this same approach, I would be hesitant to apply this finding across industries. 
Table 1. Results of Regressions of Win Percentage on Team-level Statistics, 2007-2008

\begin{tabular}{|l|l|l|}
\hline \multicolumn{1}{|c|}{ League } & $\begin{array}{l}\text { Goodness } \\
\text { of Fit (R }\end{array}$ & \multicolumn{1}{c|}{ Significant Variables } \\
\hline Major League Baseball & 0.9168 & $\begin{array}{l}\text { Hits, Stolen bases, Batting average, On-base average, } \\
\text { Earned run average, Earned runs allowed, Walks } \\
\text { allowed, Opponent walks plus hits per innings } \\
\text { pitched, Opponent stolen base success average }\end{array}$ \\
\hline $\begin{array}{l}\text { National Basketball } \\
\text { Association }\end{array}$ & 0.9777 & $\begin{array}{l}\text { Free throw attempts, Net turnovers, Opponent field } \\
\text { goal attempts, Opponent points }\end{array}$ \\
\hline National Football League & 0.6310 & Opponent points \\
\hline National Hockey League & 0.8295 & Goals per game, Ratio of Goals for to Goals Against \\
\hline
\end{tabular}

SOURCE: Author's calculations from public data on major sports teams.

NOTES: Dependent Variable is the logit of the regular season win percentage, that is, $\log \{\mathrm{wp} /[1-$ wp] \} where wp is the win percentage. One NFL team had a perfect winning regular season record, and one had a perfect losing regular season record, so for the purpose of estimating the logit specification, those winning percentages were set to 0.9999 and 0.0001 , respectively. Since there is substantial multicollinearity, other variables might be significant in a more parsimonious specification. The regression coefficients are available from the author.

Table 2. Goodness of Fit $\left(\mathrm{R}^{2}\right)$ for Win Percentage Regression Residuals on Alternate Specifications of Stardom, 2007-2008

\begin{tabular}{|l|c|c|c|c|}
\hline \multirow{2}{*}{} & \multicolumn{4}{|c|}{$\begin{array}{c}\text { Star/Superstar definition } \\
\text { (E=expansive, R=restrictive) }\end{array}$} \\
\cline { 2 - 5 } & $\mathbf{E} / \mathbf{E}$ & $\mathbf{E} / \mathbf{R}$ & $\mathbf{R} / \mathbf{E}$ & $\mathbf{R} / \mathbf{R}$ \\
\hline Major League Baseball & 0.0051 & 0.0415 & 0.0059 & 0.0424 \\
\hline National Basketball Association & 0.0056 & 0.0047 & 0.0407 & 0.0407 \\
\hline National Football League & 0.0254 & 0.0379 & 0.0504 & 0.0730 \\
\hline National Hockey League & 0.0895 & 0.0753 & 0.0158 & 0.0146 \\
\hline Pooled & 0.0071 & 0.0115 & 0.0094 & 0.0305 \\
\hline
\end{tabular}

SOURCE: Author's calculations from regressions described in Table 1 and public data on major league sports teams and players. 
Table 3 Number of Establishments in U.S. Firms Owning Professional Sports Teams, 2007

\begin{tabular}{|r|r|r|}
\hline \hline $\begin{array}{l}\text { Number of } \\
\text { establishments }\end{array}$ & $\begin{array}{l}\text { Number } \\
\text { of firms }\end{array}$ & $\begin{array}{l}\text { Average Number } \\
\text { of NAICS 2-digit } \\
\text { sectors (of 17) }\end{array}$ \\
\hline 1 & 66 & 1.0 \\
\hline 2 & 10 & 1.2 \\
\hline 3 & 10 & 2.1 \\
\hline 4 & 4 & 1.3 \\
\hline 5 & 4 & 1.8 \\
\hline $6-10$ & 6 & 4.8 \\
\hline $11-20$ & 3 & 5.7 \\
\hline $21-100$ & 3 & 7.0 \\
\hline 101 or more & 3 & \\
\hline Totals & & \\
\hline 1,959 & 109 & \\
\hline
\end{tabular}

SOURCE: U.S. Census Bureau, Standard Statistical Establishment List, 2007 (author's tabulations).

NOTE: Limited to the four major sports leagues. NAICS=North American Industry Classification System. 
Table 4: Measures of Sales, Employment, Payroll, Non-Labor Surplus (NLS), and Profit: 2007

\begin{tabular}{|c|c|c|c|c|c|c|c|c|c|}
\hline \multirow{8}{*}{ 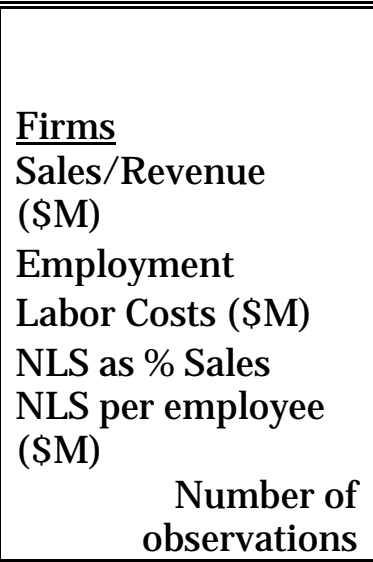 } & \multicolumn{3}{|c|}{$\begin{array}{c}\text { Economic Census data } \\
(2007)\end{array}$} & & & & & & \\
\hline & Mean & Std Dev & Median & & & & & & \\
\hline & 631.0 & 2987.4 & 177.1 & & & & & & \\
\hline & 1687.6 & 8381.2 & 348.0 & & & & & & \\
\hline & 172.8 & 449.3 & 108.0 & & & & & & \\
\hline & 37.8 & 19.1 & 34.6 & & & & & & \\
\hline & 0.216 & 0.310 & 0.156 & & & & & & \\
\hline & \multicolumn{3}{|c|}{109 firms } & & & & & & \\
\hline \multirow{8}{*}{$\begin{array}{l}\text { Teams } \\
\text { Sales/ Revenue } \\
(\$ M) \\
\text { Employment } \\
\text { Labor Costs }(\$ M) \\
\text { NLS as \% Sales } \\
\text { NLS per employee } \\
(\$ M) \quad \text { Number of }\end{array}$} & \multicolumn{6}{|c|}{ Census of Services data (2007) } & & & \\
\hline & Mean & Std Dev & Median & Mean & Std Dev & Median & & & \\
\hline & 155.5 & 69.6 & 154.6 & 159.1 & 64.0 & 163.1 & & & \\
\hline & 337.4 & 228.0 & 278.0 & 300.0 & 204.9 & 250.0 & & & \\
\hline & 102.0 & 40.7 & 98.9 & 102.3 & 33.7 & 107.8 & & & \\
\hline & 31.2 & 14.3 & 31.0 & 32.1 & 16.1 & 30.8 & & & \\
\hline & 0.211 & 0.202 & 0.149 & 0.209 & 0.166 & 0.155 & & & \\
\hline & \multicolumn{3}{|c|}{105 teams (CS sample) } & \multicolumn{3}{|c|}{30 teams (SAS sample) } & & & \\
\hline & \multicolumn{9}{|c|}{ Service Annual Survey data } \\
\hline & \multicolumn{3}{|c|}{2007} & \multicolumn{3}{|c|}{2008} & \multicolumn{3}{|c|}{2008 minus 2007} \\
\hline & Mean & Std Dev & Median & Mean & Std Dev & Median & Mean & Std Dev & Median \\
\hline \multirow{6}{*}{$\begin{array}{l}\text { Teams } \\
\text { Sales/ Revenue } \\
(\$ M) \\
\text { Labor Costs }(\$ M) \\
\text { NLS as \% Sales } \\
\text { NLS per employee } \\
\text { (\$M) } \\
\text { Profit as \% Sales } \\
\text { Profit per employee } \\
\text { (\$M) }\end{array}$} & 150.8 & 56.3 & 154.1 & 166.2 & 64.4 & 179.9 & & & \\
\hline & 101.3 & 38.4 & 106.6 & 108.4 & 45.0 & 112.6 & & & \\
\hline & 28.7 & 22.6 & 28.4 & 31.8 & 22.1 & 33.8 & 3.1 & 19.4 & 0.7 \\
\hline & 0.181 & 0.175 & 0.156 & 0.236 & 0.203 & 0.201 & 0.054 & 0.185 & 0.030 \\
\hline & -10.5 & 23.2 & -7.1 & -4.8 & 25.3 & -2.5 & 10.4 & 23.1 & 6.9 \\
\hline & -0.046 & 0.136 & -0.028 & 0.001 & 0.147 & -0.011 & 0.046 & 0.196 & 0.028 \\
\hline $\begin{array}{r}\text { Number of } \\
\text { observations }\end{array}$ & & 30 teams & & & 30 teams & & & 30 team & \\
\hline
\end{tabular}

SOURCE: U.S. Census Bureau, 2007 Economic Censuses, 2007 and 2008 Service Annual Survey.

NOTE: Std Dev=Standard Deviation 
TABLE 5. Firm-level Regressions using Economic Census Data, 2007

\begin{tabular}{|c|c|c|c|c|c|c|}
\hline \multirow{2}{*}{$\begin{array}{l}\text { Dependent Variable: } \\
\text { Independent Variable }\end{array}$} & \multicolumn{3}{|c|}{$\begin{array}{l}\text { Non-Labor Surplus (\$mn) } \\
\text { per employee }\end{array}$} & \multicolumn{3}{|c|}{$\begin{array}{l}\text { Logit of Non-Labor Surplus } \\
\text { as \% of Sales }\end{array}$} \\
\hline & Coefficient & Std Err & $\mathrm{t}$ & Coefficient & Std Err & $\mathrm{t}$ \\
\hline Constant & 0.0867 & 0.3096 & & 0.2077 & 2.1161 & \\
\hline Number of stars & -0.0108 & 0.0269 & & -0.1701 & 0.1839 & \\
\hline Number of superstars & -0.0127 & 0.0444 & & 0.1328 & 0.3032 & \\
\hline $\begin{array}{l}\text { Number of stars acquirea pre- } \\
\text { season }\end{array}$ & 0.2025 & 0.0763 & *** & 0.9973 & 0.5215 & $*$ \\
\hline Number of stars lost pre-season & -0.0205 & 0.0616 & & 0.0155 & 0.4212 & \\
\hline $\begin{array}{l}\text { Number or stars acquired mid- } \\
\text { season }\end{array}$ & -0.0746 & 0.2014 & & 0.9287 & 1.3765 & \\
\hline $\begin{array}{l}\text { Number of stars lost mid- } \\
\text { season }\end{array}$ & -0.3413 & 0.1713 & ** & -1.7623 & 1.1703 & \\
\hline $\begin{array}{l}\text { Number of superstars acquired } \\
\text { pre-season }\end{array}$ & -0.2569 & 0.1165 & ** & -1.4514 & 0.7960 & $*$ \\
\hline $\begin{array}{l}\text { Number of superstars lost pre- } \\
\text { season }\end{array}$ & 0.3619 & 0.0965 & $* * *$ & 2.0010 & 0.6598 & $* * *$ \\
\hline $\begin{array}{l}\text { Number of superstars acquired } \\
\text { mid-season }\end{array}$ & -0.2616 & 0.2742 & & -2.4765 & 1.8741 & \\
\hline $\begin{array}{l}\text { Number of superstars lost mid- } \\
\text { season }\end{array}$ & 0.3426 & 0.2430 & & 2.5709 & 1.6605 & \\
\hline Firm has two teams & 0.1240 & 0.2074 & & -0.5490 & 1.4177 & \\
\hline Firm has $>1$ establishment & 0.0309 & 0.0622 & & 0.9911 & 0.4249 & $* *$ \\
\hline Major League Baseball & 0.0355 & 0.0866 & & 0.8513 & 0.5918 & \\
\hline National Basketball Association & -0.0795 & 0.1083 & & 0.0604 & 0.7398 & \\
\hline $\begin{array}{l}\text { National Hockey League } \\
\text { Madenlavoff in nrevious? }\end{array}$ & -0.0948 & 0.1099 & & 0.6887 & 0.7512 & \\
\hline $\begin{array}{l}\text { years } \\
\text { Won championship in previous }\end{array}$ & -0.0147 & 0.0804 & & -0.3479 & 0.5491 & \\
\hline 2 years & 0.0501 & 0.1347 & & 0.1296 & 0.9204 & \\
\hline Win percentage, 2007 & 0.1510 & 0.2569 & & 1.3998 & 1.7559 & \\
\hline Win percentage, 2006 & -0.0464 & 0.2411 & & -1.3954 & 1.6475 & \\
\hline Arena age & -0.0027 & 0.0023 & & -0.0227 & 0.0158 & \\
\hline Number of playoff games & -0.0049 & 0.0070 & & -0.0502 & 0.0477 & \\
\hline $\begin{array}{l}\text { Another team in same 1 } \\
\text { exists in same metro }\end{array}$ & $\mathrm{DNP} / \mathrm{NS}$ & & & $\mathrm{DNP} / \mathrm{NS}$ & & \\
\hline MSA population (mn) & 0.0093 & 0.0102 & & 0.0667 & 0.0700 & \\
\hline MSA per capita income ( $\$$ th) & 0.0032 & 0.0074 & & 0.0231 & 0.0507 & \\
\hline $\begin{array}{l}\text { Cnange in ownersnip in } \\
\text { previous } 3 \text { years }\end{array}$ & -0.1078 & 0.0985 & & -0.2357 & 0.6731 & \\
\hline Arena financed publicly & 0.0169 & 0.0808 & & -0.3977 & 0.5525 & \\
\hline R-squared & & 3559 & & & 516 & \\
\hline
\end{tabular}

SOURCE: U.S. Census Bureau, 2007 Economic Censuses.

NOTES: 109 firms included. Uses restrictive definitions of stars and superstars. Std Err=standard error of estimate. DNP/ NS=disclosure not permitted, coefficient not significant. $* * * / * * / *=$ significant at the 0.01/ 0.05/ 0.10 level. 
Table 6. Team-Level Regressions using Census of Services Data, 2007

\begin{tabular}{|c|c|c|c|c|c|c|}
\hline Dependent Variable: & \multicolumn{3}{|c|}{$\begin{array}{l}\text { Non-Labor Surplus (\$mn) per } \\
\text { employee }\end{array}$} & \multicolumn{3}{|c|}{$\begin{array}{l}\text { Logit of Non-Labor Surplus as } \\
\% \text { of Sales }\end{array}$} \\
\hline Independent Variable & Coefficient & Std Err & $\mathrm{t}$ & Coefficient & Std Err & $\mathrm{t}$ \\
\hline Constant & 0.1779 & 0.1791 & & 0.4958 & 0.3612 & \\
\hline Number of stars & 0.0198 & 0.0157 & & 0.0711 & 0.0316 & $*$ \\
\hline Number of superstars & -0.0590 & 0.0260 & $* *$ & -0.1316 & 0.0525 & $* * *$ \\
\hline $\begin{array}{l}\text { Number of stars acquired pre- } \\
\text { season }\end{array}$ & -0.0112 & 0.0454 & & -0.1866 & 0.0915 & $*$ \\
\hline Number of stars lost pre-season & -0.0577 & 0.0341 & * & -0.0771 & 0.0688 & \\
\hline $\begin{array}{l}\text { Number of stars acquired mid- } \\
\text { season }\end{array}$ & 0.0506 & 0.1119 & & -0.0424 & 0.2256 & \\
\hline $\begin{array}{l}\text { Number of stars lost mid- } \\
\text { season }\end{array}$ & -0.0227 & 0.2037 & & 0.1290 & 0.4108 & \\
\hline $\begin{array}{l}\text { Number of superstars acquired } \\
\text { pre-season }\end{array}$ & 0.1551 & 0.0686 & $* *$ & 0.4496 & 0.1385 & *** \\
\hline $\begin{array}{l}\text { Number of superstars lost pre- } \\
\text { season }\end{array}$ & 0.0330 & 0.0532 & & 0.0341 & 0.1074 & \\
\hline $\begin{array}{l}\text { Number of superstars acquired } \\
\text { mid-season }\end{array}$ & 0.1113 & 0.1525 & & 0.3256 & 0.3075 & \\
\hline $\begin{array}{l}\text { Number of superstars lost mid- } \\
\text { season }\end{array}$ & -0.0275 & 0.2172 & & -0.2215 & 0.4381 & \\
\hline Firm has two teams & DNP/POS & & $* k *$ & $\mathrm{DNP} / \mathrm{NS}$ & & \\
\hline Firm has $>1$ establishment & -0.0041 & 0.0356 & & -0.0671 & 0.0717 & \\
\hline Major League Baseball & -0.1392 & 0.0488 & $* * *$ & -0.0382 & 0.0985 & \\
\hline National Basketball Association & -0.1865 & 0.0613 & $* * *$ & -0.2359 & 0.1237 & $*$ \\
\hline National Hockey League & -0.2532 & 0.0605 & $* * *$ & -0.3527 & 0.1220 & $* * *$ \\
\hline $\begin{array}{l}\text { Made playoff in previous } 2 \\
\text { years }\end{array}$ & 0.0487 & 0.0461 & & -0.0067 & 0.0930 & \\
\hline $\begin{array}{l}\text { Won championship in previous } \\
2 \text { years }\end{array}$ & 0.0679 & 0.0745 & & 0.0575 & 0.1503 & \\
\hline Win percentage, 2007 & 0.0967 & 0.1509 & & 0.2883 & 0.3044 & \\
\hline Win percentage, 2006 & -0.0899 & 0.1340 & & -0.3582 & 0.2703 & \\
\hline Arena age & -0.0006 & 0.0013 & & 0.0006 & 0.0026 & \\
\hline Number of playoff games & 0.0023 & 0.0039 & & 0.0084 & 0.0078 & \\
\hline $\begin{array}{l}\text { Another team in same league } \\
\text { exists in same metro }\end{array}$ & $\mathrm{DNP} / \mathrm{NS}$ & & & $\mathrm{DNP} / \mathrm{NS}$ & & \\
\hline MSA population (mn) & 0.0064 & 0.0061 & & -0.0008 & 0.0122 & \\
\hline MSA per capita income ( $\$$ th) & 0.0033 & 0.0043 & & 0.0075 & 0.0087 & \\
\hline $\begin{array}{l}\text { Change in ownership in } \\
\text { previous } 3 \text { years }\end{array}$ & -0.0626 & 0.0560 & & 0.0269 & 0.1129 & \\
\hline Arena financed publicly & 0.0169 & 0.0482 & & -0.0764 & 0.0973 & \\
\hline R-squared & & 424 & & 0 . & & \\
\hline
\end{tabular}

SOURCE: U.S. Census Bureau, 2007 Census of Services.

NOTES: 105 teams included. Uses restrictive definitions of stars and superstars. Std Err=standard error of estimate. DNP/NS=disclosure not permitted, coefficient not significant; DNP/POS=disclosure not permitted, coefficient positive. $* * * / * * / *=$ significant at the $0.01 / 0.05 / 0.10$ level.

Table 7. One-Year Effects on Non-Labor Surplus of Acquiring and Losing Stars, 2007 


\begin{tabular}{|c|c|c|c|c|}
\hline & \multicolumn{4}{|c|}{ Pre-season } \\
\hline & Add 1star & Add 1 superstar & Lose 1 star & Lose 1 superstar \\
\hline \multicolumn{5}{|c|}{ 然 } \\
\hline NLS per employee (\$M) & 0.1918 & -0.0778 & -0.0097 & 0.3649 \\
\hline NLS as proportion of sales & 0.1276 & -0.1052 & 0.0343 & 0.2185 \\
\hline \multicolumn{5}{|l|}{ Team } \\
\hline NLS per employee (\$M) & 0.0086 & 0.1047 & -0.0774 & 0.0146 \\
\hline \multirow[t]{3}{*}{ NLS as proportion of sales } & -0.0274 & 0.0460 & -0.0353 & 0.0041 \\
\hline & \multicolumn{4}{|c|}{ Mid-season } \\
\hline & \begin{tabular}{|l|l} 
Add 1 star & $A$ \\
\end{tabular} & Add 1 superstar & Lose 1star & Lose 1 superstar \\
\hline \multicolumn{5}{|l|}{ Firm } \\
\hline NLS per employee (\$M) & -0.0800 & -0.3480 & -0.3359 & 0.3490 \\
\hline NLS as proportion of sales & 0.1295 & -0.3677 & -0.3931 & 0.2338 \\
\hline \multicolumn{5}{|l|}{ Team } \\
\hline NLS pe & 0.0605 & 0.1423 & -0.0326 & 0.002 \\
\hline NLS as proportion of sales & -0.0016 & 0.0570 & 0.0216 & -0.0371 \\
\hline
\end{tabular}

SOURCE: Calculations from Tables 5 and 6 with other variables at sample means.

NOTES: NLS=Non-Labor Surplus. Uses restrictive definitions of stars and superstars. 


\begin{tabular}{|c|c|c|c|c|c|c|c|c|c|c|c|c|}
\hline \multirow{3}{*}{$\begin{array}{l}\text { Dependent Variable: } \\
\text { Independent Variable }\end{array}$} & \multicolumn{6}{|c|}{ SAS data (2007) } & \multicolumn{6}{|c|}{ SAS data (2008) } \\
\hline & \multicolumn{3}{|c|}{$\begin{array}{l}\text { Profit (\$mn) per } \\
\text { employee }\end{array}$} & \multicolumn{3}{|c|}{$\begin{array}{c}\text { Logit of Profit as \% of } \\
\text { Sales }\end{array}$} & \multicolumn{3}{|c|}{ Profit (\$mn) per employee } & \multicolumn{3}{|c|}{ Logit of Profit as \% of Sales } \\
\hline & Coefficient & Std Err & $\mathrm{t}$ & Coefficient & Std Err & $\mathrm{t}$ & Coefficient & Std Err & $\mathrm{t}$ & Coefficient & Std Err & $\mathrm{t}$ \\
\hline Constant & 0.0926 & 0.5444 & & 0.0072 & 0.0133 & & -0.4003 & 0.1973 & * & -0.5945 & 0.2719 & * \\
\hline Number of stars & 0.0244 & 0.0386 & & 0.0010 & 0.0009 & & -0.0006 & 0.0170 & & 0.0036 & 0.0235 & \\
\hline Number of superstars & -0.0016 & 0.0605 & & -0.0002 & 0.0015 & & 0.0212 & 0.0375 & & 0.0189 & 0.0517 & \\
\hline $\begin{array}{l}\text { Number of stars acquired pre- } \\
\text { season }\end{array}$ & -0.0043 & 0.1154 & & -0.0031 & 0.0028 & & -0.1027 & 0.0623 & & -0.0982 & 0.0859 & \\
\hline Number of stars lost pre-season & 0.0528 & 0.1162 & & -0.0009 & 0.0028 & & -0.2183 & 0.0668 & ** & -0.2606 & 0.0920 & $* *$ \\
\hline $\begin{array}{l}\text { Number of stars acquired mid- } \\
\text { season }\end{array}$ & 0.1413 & 0.2248 & & 0.0022 & 0.0055 & & 0.1445 & 0.1177 & & 0.1325 & 0.1622 & \\
\hline Number of stars lost mid-season & -0.4060 & 0.4405 & & 0.0019 & 0.0108 & & 0.2411 & 0.0952 & $* *$ & 0.2273 & 0.1312 & \\
\hline $\begin{array}{l}\text { Number of superstars acquired } \\
\text { pre-season }\end{array}$ & -0.0952 & 0.2518 & & 0.0018 & 0.0062 & & -0.0993 & 0.1022 & & 0.0870 & 0.1409 & \\
\hline $\begin{array}{l}\text { Number of superstars lost pre } \\
\text { season }\end{array}$ & -0.0484 & 0.1765 & & 0.0017 & 0.0043 & & 0.1914 & 0.1153 & & 0.2849 & 0.1589 & \\
\hline mid-season & (omitted) & & & (omitted) & & & -0.2762 & 0.1502 & & -0.1751 & 0.2070 & \\
\hline Firm has $>1$ establishment & -0.1175 & 0.0901 & & -0.0027 & 0.0022 & & -0.2702 & 0.0766 & $* * *$ & -0.3120 & 0.1056 & $* *$ \\
\hline Major League Baseball & 0.0623 & 0.1352 & & -0.0003 & 0.0033 & & 0.1670 & 0.0959 & & 0.1735 & 0.1321 & \\
\hline National Basketball Association & -0.0204 & 0.2311 & & 0.0002 & 0.0057 & & -0.4407 & 0.1149 & $* * *$ & -0.5297 & 0.1584 & $* *$ \\
\hline National Hockey League & -0.2751 & 0.1765 & & -0.0085 & 0.0043 & $*$ & -0.2888 & 0.0959 & ** & -0.3822 & 0.1321 & $* *$ \\
\hline Made playoff in previous 2 years & -0.0087 & 0.1496 & & -0.0015 & 0.0037 & & -0.2977 & 0.0719 & $* * *$ & -0.3194 & 0.0991 & $* *$ \\
\hline Win percentage, 2007 & -0.2258 & 0.5496 & & 0.0012 & 0.0135 & & 0.5379 & 0.1457 & $* * *$ & 0.6112 & 0.2008 & $* *$ \\
\hline Win percentage, 2006 & 0.0030 & 0.4676 & & -0.0016 & 0.0115 & & 0.1893 & 0.2018 & & 0.3159 & 0.2780 & \\
\hline Arena age & -0.0008 & 0.0045 & & 0.0001 & 0.0001 & & 0.0044 & 0.0038 & & 0.0077 & 0.0053 & \\
\hline Number of playoff games & 0.0118 & 0.0150 & & 0.0001 & 0.0004 & & 0.0187 & 0.0050 & $* * *$ & 0.0217 & 0.0069 & $* *$ \\
\hline $\begin{array}{l}\text { Another team in same league } \\
\text { exists in same metro }\end{array}$ & -0.0278 & 0.2778 & & 0.0016 & 0.0068 & & -0.1490 & 0.1400 & & -0.2864 & 0.1929 & \\
\hline MSA population (mn) & 0.0000 & 0.0205 & & -0.0004 & 0.0005 & & -0.0101 & 0.0092 & & -0.0154 & 0.0126 & \\
\hline MSA per capita income ( $\$$ th) & 0.0003 & 0.0149 & & -0.0003 & 0.0004 & & 0.0224 & 0.0047 & $* * *$ & 0.0266 & 0.0065 & $* * *$ \\
\hline $\begin{array}{l}\text { Change in ownership in previous } \\
3 \text { years }\end{array}$ & -0.1308 & 0.1852 & & -0.0015 & 0.0045 & & DNP/NEG & & *** & $\mathrm{DNP} / \mathrm{NEG}$ & & $* * *$ \\
\hline Arena financed publicly & -0.0654 & 0.1319 & & 0.0015 & 0.0032 & & -0.3303 & 0.1064 & $* *$ & -0.3328 & 0.1466 & $*$ \\
\hline R-squared & \multicolumn{3}{|c|}{0.6755} & \multicolumn{3}{|c|}{0.7950} & \multicolumn{3}{|c|}{0.9332} & \multicolumn{3}{|c|}{0.9406} \\
\hline
\end{tabular}


SOURCE: U.S. Census Bureau, 2007 and 2008 Service Annual Survey.

NOTE: 30 teams included. Uses restrictive definitions of stars and superstars. Std Err=standard error of estimate. (omitted) $=$ omitted due to multicollinearity (Number of superstars lost mid-season also omitted). DNP/NEG=disclosure not permitted, coefficient negative. $* * * / * * / *=$ significant at the 0.01/0.05/0.10 level. 
Table 9. Team-Level Regressions of Change from 2007 to 2008 using Service Annual Survey Data

\begin{tabular}{|c|c|c|c|c|c|c|c|c|c|c|c|c|}
\hline \multirow{2}{*}{$\begin{array}{l}\text { Dependent Variable: } \\
\text { Independent Variable }\end{array}$} & \multicolumn{3}{|c|}{$\begin{array}{l}\text { Non-Labor Surplus } \\
\text { (\$mn) per employee }\end{array}$} & \multicolumn{3}{|c|}{$\begin{array}{c}\text { Logit of Non-Labor } \\
\text { Surplus as \% of Sales }\end{array}$} & \multicolumn{3}{|c|}{ Profit (\$mn) per employee } & \multicolumn{3}{|c|}{ Logit of Profit as \% of Sales } \\
\hline & Coefficient & Std Err & $\mathrm{t}$ & Coefficient & Std Err & $\mathrm{t}$ & Coefficient & Std Err & $\mathrm{t}$ & Coefficient & Std Err & $\mathrm{t}$ \\
\hline Constant & 0.0032 & 0.0898 & & -0.9152 & 0.6742 & & 0.0213 & 0.0870 & & -1.0138 & 0.0942 & $* * *$ \\
\hline $\begin{array}{l}\text { Number of stars acquired } \\
\text { pre-season }\end{array}$ & 0.0624 & 0.1052 & & -0.4297 & 0.7893 & & 0.0024 & 0.1019 & & 0.0402 & 0.1102 & \\
\hline $\begin{array}{l}\text { Number of stars lost pre- } \\
\text { season }\end{array}$ & -0.0168 & 0.1058 & & 1.3989 & 0.7938 & $*$ & -0.0087 & 0.1024 & & 0.1688 & 0.1109 & \\
\hline $\begin{array}{l}\text { Number of stars acquired } \\
\text { mid-season }\end{array}$ & 0.2335 & 0.2374 & & 1.3771 & 1.7811 & & 0.1794 & 0.2299 & & 0.4997 & 0.2487 & $*$ \\
\hline $\begin{array}{l}\text { Number of stars lost mid- } \\
\text { season }\end{array}$ & -0.1838 & 0.1415 & & 0.7565 & 1.0616 & & -0.0767 & 0.1370 & & -0.0442 & 0.1483 & \\
\hline $\begin{array}{l}\text { Number of superstars } \\
\text { acquired pre-season } \\
\text { Number of sunerstars lost }\end{array}$ & 0.0197 & 0.1538 & & 1.2491 & 1.1541 & & 0.0428 & 0.1490 & & 0.1352 & 0.1612 & \\
\hline $\begin{array}{l}\text { pre-season } \\
\text { Number of superstars }\end{array}$ & 0.0507 & 0.1442 & & -2.8780 & 1.0819 & $* *$ & 0.0692 & 0.1396 & & -0.4144 & 0.1511 & $* *$ \\
\hline acquired mid-season & -0.2459 & 0.2933 & & -1.0622 & 2.2007 & & -0.3168 & 0.2840 & & -0.2807 & 0.3073 & \\
\hline $\begin{array}{l}\text { Number of superstars lost } \\
\text { mid-season }\end{array}$ & 0.1386 & 0.2637 & & 0.3426 & 1.9785 & & 0.0052 & 0.2554 & & 0.0662 & 0.2763 & \\
\hline $\begin{array}{l}\text { Major League Baseball } \\
\text { National Basketball }\end{array}$ & 0.0029 & 0.1079 & & -1.4966 & 0.8094 & & -0.0231 & 0.1045 & & -0.1751 & 0.1130 & \\
\hline Association & 0.0186 & 0.1369 & & -0.0813 & 1.0270 & & -0.0102 & 0.1326 & & 0.1088 & 0.1434 & \\
\hline National Hockey League & 0.1761 & 0.1327 & & -0.9416 & 0.9961 & & 0.2407 & 0.1286 & $*$ & -0.1503 & 0.1391 & \\
\hline $\begin{array}{l}\text { Change in win percentage, } \\
2008-2007\end{array}$ & -0.1531 & 0.1828 & & -0.9167 & 1.3716 & & 0.0886 & 0.1770 & & 0.1734 & 0.1916 & \\
\hline $\begin{array}{l}\text { Change in number of playoff } \\
\text { games, 2008-2007 }\end{array}$ & 0.0199 & 0.0081 & $* *$ & 0.0220 & 0.0609 & & 0.0181 & 0.0079 & ** & 0.0128 & 0.0085 & \\
\hline R-squared & & 726 & & & 116 & & 0.5 & & & & 743 & \\
\hline
\end{tabular}

SOURCE: U.S. Census Bureau, 2007 and 2008 Service Annual Survey.

NOTE: 30 teams included. Uses restrictive definitions of stars and superstars. Std Err=standard error of estimate. NLS=Non-Labor Surplus. $* * * / * * / *=$ significant at the 0.01/ 0.05/0.10 level. 


\section{REFERENCES}

Adler, Moshe. 1985. “Stardom and Talent.” American Economic Review 75(1): 208-12.

Andersson, Frederik, Matthew Friedman, J ohn Haltiwanger, J ulia Lane, and Kathryn Shaw. 2009. "Reaching for the Stars: Who Pays for Talent in Innovative Industries?” Economic J ournal 119 (J une): F308- 32.

Berman, Shawn L. J onathan Down, and Charles W.L. Hill. 2002. “Tacit Knowledge as a Source of Competitive Advantage in the National Basketball Association.” Academy of Management J ournal 45(1): 13-31.

Berri, David J ., Martin B. Schmidt, and Stacey L. Brook. 2004. "Stars at the Gate: The Impact of Star Power on NBA Gate Revenues.” J ournal of Sports Economics 5(1) (February): 33-50.

Brown, E., R. Spiro, and D. Keenan. 1991. “Wage and Non-wage Discrimination in Professional Basketball: Do Fans Affect It?” American J ournal of Economics and Sociology 50(3) (J uly): 333-345.

Burdekin, R.C. and T.L. Idson. 1991. "Customer Preferences, Attendance, and the Racial Structure of Professional Basketball Teams.” Applied Economics 23: 179-186.

Campbell, Benjamin, Martin Ganco, April Franco, and Rajshree Agarwal. 2009. “Who Leaves, Where to, and Why Worry? Employee Mobility, Employee Entrepreneurship, and Effects on Source Firm Performance." U.S. Census Bureau Center for Economic Studies Discussion Paper CES-WP-09-32. September.

Carnahan, Seth, Rajshree Agarwal, Benjamin Campbell, and April Franco. 2010. "The Effect of Firm Compensation Structures on Employee Mobility and Employee Entrepreneurship of Extreme Performers." U.S. Census Bureau Center for Economic Studies Discussion Paper CES-WP-10-06. March.

Clarke, J onathan, Ajay Khorana, Ajay Patel, and P. Raghavendra Rau. 2007. 'The Impact of All-star Analyst J ob Changes on their Coverage Choices and Investment Banking Deal Flow." J ournal of Financial Economics 84(3) (J une): 713-737.

Davis, Michael C. “New Franchise Location in Major- and Minor-League Baseball.” Chapter 8 in Brad R. Humphries and Dennis R. Howard (eds.) The Business of Sports Volume 3: Bridging Research and Practice. Westport CT: Praeger, 2008. Pp. 147-166.

Dunne, Timothy, Shawn Klimek, Mark Roberts, and Yi Xu. 2007. 'The Dynamics of Market Structure and Market Size in Two Health Services Industries.” U.S. Census Bureau Center for Economic Studies Discussion Paper CES-WP-07-26. October.

Franck, Egon and Stephan Nüesch. 2012. “Talent and/ or Popularity: What Does it Take to be a Superstar?” Economic Inquiry 50(1) (J anuary): 202-216.

Frick, Bernd and Rob Simmons. "Pay and Performance of Players in Sports Leagues: International Comparisons." Chapter 7 in Brad R. Humphries and Dennis R. Howard (eds.) The Business of Sports Volume 2: Economic Perspectives on Sport. Westport CT: Praeger, 2008. Pp. 153-180.

Gardner, Timothy M. 2005. “Interfirm Competition for Human Resources: Evidence from the Software Industry." Academy of Management J ournal 48(2): 237-256.

Garicano, Luis and Thomas N. Hubbard. 2009. "Specialization, Firms, and Markets: The Division of Labor within and between Law Firms.” J ournal of Law, Economics, and Organization 25(2): 339-371.

Gladwell, Malcom. 2011. "The Nets and NBA Economics.”

http:// www.grantland.com/ story/_/id/ 7021031/the-nets-nba-economics; accessed 4 March 2013. 
Glenn, Andrew, J oseph P. McGarrity, and J im Weller. 2001. “Firm-specific Human Capital, J ob Matching, and Turnover: Evidence from Major League Baseball, 1900- 1992." Economic Inquiry 39(1) (J anuary): 86- 93.

Groysberg, Boris, Linda-Eling Lee, and Ashish Nanda. 2008. "Can They Take It With Them? The Portability of Star Knowledge Workers' Performance.” Management Science 54(7) (J uly): 1213-1230.

Hausman, J erry A. and Gregory K. Leonard. 1997. "Superstars in the National Basketball Association: Economic Value and Policy.”J ournal of Labor Economics 15(4): 586-624.

Humphries, Brad R. and Dennis R. Howard. 2008. The Business of Sports. Volume 1: Perspectives on the Sports Industry. Westport CT: Praeger.

Ichniowski, Casey and Anne E. Preston. 2012. "Does March Madness Lead to Irrational Exuberance in the NBA Draft? High-Value Employee Selection Decisions and Decision-Making Bias.” NBER Working Paper No. 17928, March.

Kahn, Lawrence M. 2000, “The Sports Business as a Labor Market Laboratory.” J ournal of Economic Perspectives 13(3) Summer, pp. 75-94, Excerpted in Chapter 9 of Scott R. Rosner and Kenneth L. Shropshire (eds.) The Business of Sports. Boston: J ones and Bartlett, 2004. Pp. 242-251.

Kouvet, Don. 1977. The Rich Who Own Sports. New York: Random House. Excerpted in Chapter 1 of Scott R. Rosner and Kenneth L. Shropshire (eds.) The Business of Sports. Boston: J ones and Bartlett, 2004. Pp. 5-7.

Krautmann, Anthony C. and Margaret Oppenheimer. 1994. "Free Agency and the Allocation of Labor in Major League Baseball.” Managerial and Decision Economics 15 (5) (September/October): 459- 469.

Lazear, Edward P. and Paul Oyer. 2007. “Personnel Economics.” NBER Working Paper 13480. October.

Lazear, Edward P. and Kathryn L. Shaw. 2007. “Personnel Economics: The Economist’s View of Human Resources.” J ournal of Economic Perspectives 21(4) (Fall): 91-114.

Lenzi, Camilla. 2009, “Patterns and Determinants of Skilled Workers' Mobility: Evidence from a Survey of Italian Inventors.” Economics of Innovation and New Technology 18 (2) (March): 161-179.

Limehouse, Frank, and Robert McCormick. 2011. "Impacts of Central Business District Location: A Hedonic Analysis of Legal Service Establishments.” U.S. Census Bureau Center for Economic Studies Discussion Paper CES-WP-11-21. July.

MacDonald, Don N. and Morgan O. Reynolds. 1994. "Are Baseball Players Paid their Marginal Products?" Managerial and Decision Economics (5) (September/ October): 443- 457.

Mason, Daniel S. and Dennis R. Howard. 2008. "New Revenue Streams in Professional Sports." Chapter 6 in Brad R. Humphries and Dennis R. Howard (eds.) The Business of Sports Volume 1: Perspectives on the Sports Industry. Westport CT: Praeger, 2008. Pp. 125-151.

Miller, Phillip A. 2007. "Revenue Sharing on Sports Leagues: The Effects on Talent Redistribution and Competitive Balance.”J ournal of Sports Economics 8(1): (February): 62-82.

Oyer, Paul and Scott Schaefer. 2011. "Personnel Economics: Hiring and Incentives.” Chapter 20 in Orley Ashenfelter and David Card (eds.) Handbook of Labor Economics, Vol. 4B.

Quirk, J ames and Rodney D. Fort. 1992. Pay Dirt: The Business of Professional Team Sports. Princeton University Press. Excerpted in Chapter 9 of Scott R. Rosner and Kenneth L. Shropshire (eds.) The Business of Sports. Boston: J ones and Bartlett, 2004. Pp. 235-241. 
Rascher, Daniel A. "Franchise Relocations, Expansions, and Mergers in Professional Sports Leagues. In Brad R. Humphries and Dennis R. Howard (eds.) The Business of Sports Volume 2: Economic Perspectives on Sport. Westport CT: Praeger, 2008. Pp. 67-105.

Ravid, S. Abraham. 1999. “Information, Blockbusters, and Stars: A Study of the Film Industry.” J ournal of Business 72(4) (October): 463-492.

Rosen, Sherwin. 1981. 'The Economics of Superstars.” American Economic Review 71(5) (December): 845858.

Rosner, Scott R. and Kenneth L. Shropshire (eds.). 2004. The Business of Sports. Boston: J ones and Bartlett.

Scott, F., J r., J . Long, and K. Sompii. 1985. "Salary vs. Marginal Revenue Product under Monopsony Competition: The Case of Professional Basketball.” Atlanta Economic J ournal 13(3): 50-59.

Scully, Gerald W. 1995. The Market Structure of Sports. Chicago: University of Chicago Press. Excerpted in Chapter 2 of Scott R. Rosner and Kenneth L. Shropshire (eds.) The Business of Sports. Boston: J ones and Bartlett, 2004. Pp. 26-33.

Shaw, Kathryn and Edward F. Lazear. 2008. “Tenure and Output.” Labour Economics 15: 705-724.

Silk, Alvin, and Charles King III. 2009. "Concentration Levels in the U.S. Advertising and Marketing Services Industry: Myth vs. Reality.” U.S. Census Bureau Center for Economic Studies Discussion Paper CES-WP-09-16. August.

Stroz, Eugene P., J r. 2001. “Public Ownership of Sports Franchises: Investment, Novelty, or Fraud?” Rutgers Law Review 53(517), Winter. Excerpted in Chapter 1 of Scott R. Rosner and Kenneth L. Shropshire (eds.) The Business of Sports. Boston: J ones and Bartlett, 2004. Pp. 15-20.

Stewart, Kenneth G. and J .C.H. J ones. 2010. “Are Sports Teams Multiproduct Firms?” Empirical Economics 39(2): 487-514.

U.S. Census Bureau. 2000. 1997 Economic Census: Comparative Statistics [for United States: 1987 SIC Basis: Service Industries]. 1997 Economic Census Report EC97X-CS2. J une; revised 2011. http:// www.census.gov/ epcd/ ec97sic/ E97SUSI.HTM\#I79; accessed 13 February 2012.

Yang, Yupin and Mengze Shi. 2011. "Rise and Fall of Stars: Investigating the Evolution of Star Status in Professional Team Sports.” International J ournal of Research in Marketing 28(4) (December): 352- 366.

Zimbalist, Andrew. 2011. Circling the Bases: Essays on the Challenges and Prospects of the Sports Industry. Philadelphia: Temple University Press.

Zucker, Lynne G., Michael R. Darby, and Maximo Torero. 2002. "Labor Mobility from Academia to Commerce.” J ournal of Labor Economics 20 (3) (J uly): 629-660. 


\section{APPENDIX A. INDEPENDENT VARIABLES}

Table A-1: Independent Variables, All US Teams: 2007-2008

\begin{tabular}{|c|c|c|c|c|c|c|c|c|c|}
\hline \multirow{2}{*}{\multicolumn{2}{|c|}{ Independent Variables }} & \multicolumn{4}{|c|}{2007} & \multicolumn{4}{|c|}{2008} \\
\hline & & Mean & $\begin{array}{l}\text { Std } \\
\text { Dev }\end{array}$ & $\begin{array}{l}\text { Mini- } \\
\text { mum }\end{array}$ & $\begin{array}{l}\text { Maxi- } \\
\text { mum }\end{array}$ & Mean & $\begin{array}{l}\text { Std } \\
\text { Dev }\end{array}$ & $\begin{array}{l}\text { Mini- } \\
\text { mum }\end{array}$ & $\begin{array}{l}\text { Maxi- } \\
\text { mum }\end{array}$ \\
\hline \multicolumn{2}{|c|}{$\begin{array}{l}\text { Major League Baseball team } \\
(0 / 1)\end{array}$} & 0.254 & 0.436 & 0 & (1) & 0.254 & 0.436 & 0 & The \\
\hline \multicolumn{2}{|c|}{$\begin{array}{l}\text { National Basketball } \\
\text { Association team }(0 / 1)\end{array}$} & 0.254 & 0.436 & 0 & 1 & 0.254 & 0.436 & 0 & 1 \\
\hline \multicolumn{2}{|c|}{$\begin{array}{l}\text { National Football League } \\
\text { team }(0 / 1)\end{array}$} & 0.281 & 0.449 & 0 & 1 & 0.281 & 0.449 & 0 & 1 \\
\hline \multicolumn{2}{|c|}{$\begin{array}{l}\text { National Hockey League } \\
\text { team }(0 / 1)\end{array}$} & 0.211 & 0.408 & 0 & 1 & 0.211 & 0.408 & 0 & 1 \\
\hline \multicolumn{2}{|c|}{$\begin{array}{l}\text { Made playoff in previous } 2 \\
\text { years? }(0 / 1)\end{array}$} & 0.377 & 0.485 & 0 & 1 & 0.272 & 0.445 & 0 & 1 \\
\hline \multicolumn{2}{|c|}{$\begin{array}{l}\text { Won championship in } \\
\text { previous } 2 \text { years? (0/ 1) }\end{array}$} & 0.070 & 0.255 & 0 & 1 & 0.070 & 0.255 & 0 & 1 \\
\hline \multicolumn{2}{|c|}{ Made Playoff this year (0/ 1$)$} & 0.360 & 0.480 & 0 & 1 & 0.342 & 0.474 & 0 & 1 \\
\hline \multicolumn{2}{|c|}{ Win percentage this year } & 0.500 & 0.144 & 0.063 & 1.000 & 0.501 & 0.149 & 0.000 & 0.813 \\
\hline \multirow{2}{*}{\multicolumn{2}{|c|}{$\begin{array}{l}\text { Win percentage last year } \\
\text { Playoff games played this } \\
\text { year }\end{array}$}} & 0.498 & 0.129 & 0.125 & 0.875 & 0.501 & 0.145 & 0.063 & 1.000 \\
\hline & & 3.439 & 5.778 & 0 & 26 & 3.596 & 5.985 & 0 & 24 \\
\hline \multicolumn{2}{|l|}{ Age of arena } & 15.474 & 15.354 & 0 & 95 & 16.061 & 15.159 & 0 & 96 \\
\hline \multicolumn{2}{|c|}{$\begin{array}{l}\text { Number of other sports } \\
\text { teams same metro area, } \\
\text { same league }\end{array}$} & 0.211 & 0.468 & 0 & 2 & 0.211 & 0.468 & 0 & 2 \\
\hline \multicolumn{2}{|c|}{$\begin{array}{l}\text { Metropolitan area } \\
\text { population (millions) }\end{array}$} & 5.606 & 4.872 & 0.303 & 19.007 & 5.561 & 4.851 & 0.301 & 18.923 \\
\hline \multicolumn{2}{|c|}{$\begin{array}{l}\text { Metropolitan area per capita } \\
\text { income ( } \$ \text { thousands) }\end{array}$} & 29.726 & 4.344 & 20.311 & 40.899 & 25.542 & 5.230 & 17.417 & 40.511 \\
\hline \multirow{2}{*}{\multicolumn{2}{|c|}{$\begin{array}{l}\text { Change in ownership in } \\
\text { previous } 3 \text { years? (0/1) } \\
\text { Is arena publically financed? } \\
(0 / 1)\end{array}$}} & 0.132 & 0.338 & 0 & 1 & 0.061 & 0.240 & 0 & 1 \\
\hline & & 0.754 & 0.430 & 0 & 1 & 0.754 & 0.430 & 0 & 1 \\
\hline \multicolumn{10}{|c|}{$\begin{array}{l}\text { Number of Stars and } \\
\text { Superstars }\end{array}$} \\
\hline \multirow{5}{*}{$\begin{array}{l}\text { STARS - } \\
\text { Expansive } \\
\text { definition }\end{array}$} & $\begin{array}{l}\text { Number on } \\
\text { team }\end{array}$ & 3.868 & 2.318 & 0 & 9.5 & 3.934 & 2.359 & 0 & 10.5 \\
\hline & $\begin{array}{l}\text { Number } \\
\text { acquired } \\
\text { pre-season }\end{array}$ & 0.640 & 0.829 & 0 & 4 & 0.570 & 0.794 & 0 & 3 \\
\hline & $\begin{array}{l}\text { Number } \\
\text { lost pre- } \\
\text { season }\end{array}$ & 0.763 & 0.939 & 0 & 4 & 0.658 & 0.935 & 0 & 4 \\
\hline & $\begin{array}{l}\text { Number } \\
\text { acquired } \\
\text { mid-season }\end{array}$ & 0.105 & 0.307 & 0 & 1 & 0.211 & 0.468 & 0 & 2 \\
\hline & Number & 0.105 & 0.360 & 0 & 2 & 0.202 & 0.443 & 0 & 2 \\
\hline
\end{tabular}




\begin{tabular}{|c|c|c|c|c|c|c|c|c|c|}
\hline & $\begin{array}{l}\text { lost mid- } \\
\text { season }\end{array}$ & & & & & & & & \\
\hline \multirow{5}{*}{$\begin{array}{l}\text { SUPERSTARS } \\
\text { - Expansive } \\
\text { definition }\end{array}$} & $\begin{array}{l}\text { Number on } \\
\text { team }\end{array}$ & 1.711 & 1.476 & 0 & 6 & 1.754 & 1.685 & 0 & 8 \\
\hline & $\begin{array}{l}\text { Number } \\
\text { acquired } \\
\text { pre-season }\end{array}$ & 0.219 & 0.526 & 0 & 3 & 0.175 & 0.500 & 0 & 3 \\
\hline & $\begin{array}{l}\text { Number } \\
\text { lost pre- } \\
\text { season }\end{array}$ & 0.237 & 0.501 & 0 & 2 & 0.228 & 0.478 & 0 & 2 \\
\hline & $\begin{array}{l}\text { Number } \\
\text { acquired } \\
\text { mid-season }\end{array}$ & 0.044 & 0.205 & 0 & 1 & 0.114 & 0.318 & 0 & 1 \\
\hline & $\begin{array}{l}\text { Number } \\
\text { lost mid- } \\
\text { season }\end{array}$ & 0.044 & 0.244 & 0 & 2 & 0.096 & 0.295 & 0 & 1 \\
\hline \multirow{5}{*}{$\begin{array}{l}\text { STARS - } \\
\text { Restrictive } \\
\text { definition }\end{array}$} & $\begin{array}{l}\text { Number on } \\
\text { team }\end{array}$ & 2.711 & 1.953 & 0 & 8 & 2.763 & 2.200 & 0 & 9 \\
\hline & $\begin{array}{l}\text { Number } \\
\text { acquired } \\
\text { pre-season }\end{array}$ & 0.377 & 0.613 & 0 & 3 & 0.298 & 0.620 & 0 & 3 \\
\hline & $\begin{array}{l}\text { Number } \\
\text { lost pre- } \\
\text { season }\end{array}$ & 0.412 & 0.673 & 0 & 2 & 0.360 & 0.664 & 0 & 3 \\
\hline & $\begin{array}{l}\text { Number } \\
\text { acquired } \\
\text { mid-season }\end{array}$ & 0.053 & 0.223 & 0 & 1 & 0.175 & 0.424 & 0 & 2 \\
\hline & $\begin{array}{l}\text { Number } \\
\text { lost mid- } \\
\text { season }\end{array}$ & 0.053 & 0.260 & 0 & 2 & 0.158 & 0.410 & 0 & 2 \\
\hline \multirow{5}{*}{$\begin{array}{l}\text { SUPERSTARS } \\
\text { - Restrictive } \\
\text { definition }\end{array}$} & $\begin{array}{l}\text { Number on } \\
\text { team }\end{array}$ & 1.132 & 1.126 & 0 & 5 & 1.162 & 1.268 & 0 & 6 \\
\hline & $\begin{array}{l}\text { Number } \\
\text { acquired } \\
\text { pre-season }\end{array}$ & 0.158 & 0.410 & 0 & 2 & 0.114 & 0.369 & 0 & 2 \\
\hline & $\begin{array}{l}\text { Number } \\
\text { lost pre- } \\
\text { season }\end{array}$ & 0.158 & 0.410 & 0 & 2 & 0.149 & 0.380 & 0 & 2 \\
\hline & $\begin{array}{l}\text { Number } \\
\text { acquired } \\
\text { mid-season }\end{array}$ & 0.026 & 0.160 & 0 & 1 & 0.088 & 0.283 & 0 & 1 \\
\hline & $\begin{array}{l}\text { Number } \\
\text { lost mid- } \\
\text { season }\end{array}$ & 0.026 & 0.160 & 0 & 1 & 0.079 & 0.270 & 0 & 1 \\
\hline
\end{tabular}

SOURCE: Public data from databasebasketball.com, mlb.com, nba.com, nfl.com, nhl.com, wikipedia.com.

NOTES: 2007 and 2008 NBA and NHL seasons defined as seasons ending that year. Std Dev=Standard Deviation. 


\section{APPENDIX B. DEFINITIONS OF STARDOM VARIABLES}

\section{B.1 Number of Stars/Superstars ${ }^{42}$}

\section{B.1.1 Major League Baseball}

Statistical categories:

For hitters: Batting average, on-base plus slugging percentage, ${ }^{43}$ hits, home runs, runs batted in (at least 3.1 plate appearances per team game).

For pitchers: earned run average, ${ }^{44}$ saves, strikeouts, hits allowed per at bat, walks and hits allowed per inning pitched (at least 1.0 innings pitched per team game).

For catchers: percentage of base runners caught stealing (at least 0.2 stolen base attempts per team game).

For non-pitching fielders: errors per total chances (at least 0.5 games played per team game). Stars: All-star team in two or three of past 3 seasons, OR In top 5\% in a major statistical category five times (expansive) or six times (restrictive) in past 3 seasons, OR Received one major award in past 3 seasons (both), OR Received two minor awards in past 3 seasons (expansive only).

Superstars: All-star team in two or three of past 3 seasons, OR In top 1\% in a major statistical category three times (expansive) or four times (restrictive) in past 3 seasons, OR Received one (expansive) or two (restrictive) major awards in past 3 seasons (both), OR Received two minor awards in past 3 seasons (expansive only).

Major Awards: American/ National League Most Valuable Player, Offensive Player of the Year, Cy Young (best pitcher), Relief Pitcher (2004-6), Delivery Man of the Year (one for MLB, 2007). Minor Awards: American/ National League Gold Glove (best fielder at each position), Silver Slugger (best offensive player at each position).

Table B-1. Number of Major League Baseball Players in Top 1\% and 5\%

\begin{tabular}{|c|r|r|r|r|}
\hline MLB season & \# hitters & \# pitchers & \# catchers & \# fielders \\
\hline 2004 & 1135 & 631 & 107 & 1242 \\
\hline top 5\% & 57 & 32 & 5 & NC \\
\hline top 1\% & 11 & 6 & 1 & NC \\
\hline 2005 & 1141 & 606 & 103 & 1228 \\
\hline top 5\% & 57 & 30 & 5 & NC \\
\hline top 1\% & 11 & 6 & 1 & NC \\
\hline 2006 & 1133 & 635 & 104 & 1233 \\
\hline top 5\% & 57 & 32 & 5 & NC \\
\hline
\end{tabular}

\footnotetext{
${ }^{42}$ The player and team statistics were obtained from databasebasketball.com, mlb.com, nba.com, nfl.com, nhl.com, and wikipedia.com. No player is identified as a superstar unless that person is also a star using the restrictive definition.

43 The number of times each batter reaches base by hit, walk, or hit by pitch, divided by plate appearances including at-bats, walks, hit by pitch and sacrifice flies at-bats, walks, hit by pitch and sacrifice flies; plus total bases divided by at bats.

44 The total number of earned runs allowed by the pitcher multiplied by 9 , divided by the number of innings pitched.
} 


\begin{tabular}{|c|r|r|r|r|}
\hline top 1\% & 11 & 6 & 1 & NC \\
\hline 2007 & 1174 & 666 & 105 & 1273 \\
\hline top $5 \%$ & 59 & 33 & 5 & NC \\
\hline top $1 \%$ & 12 & 7 & 1 & NC \\
\hline
\end{tabular}

NOTE: NC=not computed

\section{B.1.2 National Basketball Association}

Statistical categories: Points per game played (PPG), field goal percentage (FG\%), assists per game (APG), rebounds per game (RPG), steals plus blocks minus turnovers per game (SBTPG). To be eligible, players must have appeared in at least 70 games, played 2000 minutes, or scored 1400 points (PPG and FG\%); had 400 assists (APG); had 800 rebounds (RPG); or had 125 steals or 100 blocks (SBTPG).

Stars: All-star team in two or three of past 3 seasons, OR In top 5\% in a major statistical category thrice (expansive) or four times (restrictive) in past 3 seasons, OR on first, second, or third all-NBA team or first or second all-NBA defensive team twice in past 3 seasons.

Superstars: All-star team in two or three of past 3 seasons; OR In top 1\% in a major statistical category twice (expansive) or thrice (restrictive) in past 3 seasons; OR on first, second, or third all-NBA team or first or second all-NBA defensive team twice (expansive), or on first or second all-NBA team or first all-NBA defensive team thrice (restrictive) in past 3 seasons.

Note: Most Valuable Player and Defensive Player of the Year awardees were all selected for all the relevant all-NBA teams so are not included separately above.

Table B-2. Number of National Basketball Association Players in Top 1\% and 5\%

\begin{tabular}{|c|r|}
\hline $\begin{array}{l}\text { NBA } \\
\text { season }\end{array}$ & \# players \\
\hline $2003-4$ & 441 \\
\hline top 5\% & 22 \\
\hline top 1\% & 4 \\
\hline $2004-5$ & 467 \\
\hline top 5\% & 23 \\
\hline top 1\% & 45 \\
\hline $2005-6$ & 460 \\
\hline top 5\% & 23 \\
\hline top 1\% & 5 \\
\hline $2006-7$ & 458 \\
\hline top 5\% & 23 \\
\hline top 1\% & 5 \\
\hline
\end{tabular}

\section{B.1.3 National Football League}

Statistical categories:

For quarterbacks: quarterback rating, yards per game, yards per pass (at least 14 attempts per team game).

For rushers: total rushing yards and rushing yards per game (at least 6.25 rushes per team game). 
For receivers: number of receptions, total receiving yards and receiving yards per game (at least 1.875 catches per team game).

For kick returners: yards per return (at least 10 returns).

For kickers: number of field goals made (at least 0.75 field goal attempts per team game), yards per kickoff, net yards per punt (for the latter two, at least 20 kicks/ punts).

For defense: number of tackles, number of sacks (10 or more for top 5\%, 15 or more for top 1\%), number of interceptions ( 5 or more for top $5 \%, 8$ or more for top $1 \%$ ).

Stars: All-star team in two or three of past 3 seasons, OR In top 5\% in a major statistical category two times (quarterbacks and kickers, or expansive) or three times (restrictive for offense and defense) in past 3 seasons, OR Received one major award in past 3 seasons (both). Superstars: All-star team in two (expansive) or three (restrictive) of past 3 seasons, OR In top $1 \%$ in a major statistical category two times (quarterbacks and kickers, or expansive) or three times (restrictive for offense and defense) in past 3 seasons, OR Received one major award in past 3 seasons (both).

Major Awards: Most Valuable Player, Offensive Player of the Year, Defensive Player of the Year.

Note: Each year, there are roughly 35-40 kickers, punters, and kickoff specialists. The top two of each kicking subspecialty were deemed to be in the top $5 \%$, and the top one was deemed to be in the top $1 \%$.

Table B-3. Number of National Football League Players in Top 1\% and 5\%

\begin{tabular}{|r|r|r|r|r|}
\hline NFL season & \# tacklers & \# quarterbacks & \# rushers & \# receivers \\
\hline 2004 & 1420 & 76 & 330 & 470 \\
\hline top 5\% & 71 & 4 & 17 & 24 \\
\hline top $\%$ & 14 & 1 & 3 & 5 \\
\hline 2005 & 1435 & 74 & 312 & 463 \\
\hline top 5\% & 72 & 4 & 16 & 23 \\
\hline top $1 \%$ & 14 & 1 & 3 & 5 \\
\hline 2006 & 1418 & 70 & 312 & 446 \\
\hline top $5 \%$ & 71 & 4 & 16 & 22 \\
\hline top $1 \%$ & 14 & 1 & 3 & 4 \\
\hline 2007 & 1447 & 81 & 319 & 464 \\
\hline top 5\% & 72 & 4 & 16 & 23 \\
\hline top $1 \%$ & 14 & 1 & 3 & 5 \\
\hline
\end{tabular}

NOTE: Each year, there are roughly 35-40 kickers, punters, and kickoff specialists. The top two of each kicking subspecialty are deemed to be in the top $5 \%$, and the top one is deemed to be in the top $1 \%$.

\section{B.1.4 National Hockey League}

Statistical categories:

For skaters: points, shooting percentage (at least 0.625 points per team game).

For goalies: save percentage (at least 1.0 shot attempt by opponents per team game). 
Stars: All-star team in two or three of past 3 seasons, OR In top 5\% in a major statistical category twice (once for goalies) (expansive) or thrice (twice for goalies) (restrictive) in past 3 seasons, OR Received one major award in past 3 seasons.

Superstars: All-star team in two or three of past 3 seasons, OR In top 1\% in a major statistical category once (expansive) or twice (once for goalies) (restrictive) in past 3 seasons, OR Received two major awards in past 3 seasons.

Major Awards: Art Ross Trophy (Top Point Scorer), Conn Smythe Trophy (Most Valuable Player in the Stanley Cup Playoffs), Frank J . Selke Trophy (Top Defensive Forward), Hart Memorial Trophy (Most Valuable Player), J ames Norris Memorial Trophy (Top Defenseman), Lester B. Pearson Award (Most Valuable Player as Selected by the NHL Players Association), Vezina Trophy (Top Goalie).

Note: "Past 3 seasons" excludes the lockout year of 2004-2005 and therefore includes the 20032004 season.

Table B-4. Number of National Hockey League Players in Top 1\% and 5\%

\begin{tabular}{|l|r|r|}
\hline $\begin{array}{l}\text { NHL } \\
\text { season }\end{array}$ & \# skaters & \# goalies \\
\hline $2002-3$ & 888 & 113 \\
\hline top 5\% & 44 & 6 \\
\hline top 1\% & 9 & 1 \\
\hline $2003-4$ & 916 & 112 \\
\hline top 5\% & 46 & 6 \\
\hline top 1\% & 9 & 1 \\
\hline $2005-6$ & 870 & 91 \\
\hline top 5\% & 44 & 5 \\
\hline top 1\% & 9 & 1 \\
\hline $2006-7$ & 858 & 84 \\
\hline top 5\% & 43 & 4 \\
\hline top 1\% & 9 & 1 \\
\hline
\end{tabular}

\section{B.2 Turnover variables}

Eight variables are defined for each team, and vary according to the star/ superstar definition used. These are:

Number of stars/ superstars lost pre-season

Number of stars/ superstars acquired pre-season

Number of stars/ superstars lost mid-season

Number of stars/ superstars acquired mid-season

If a player is traded mid-season, he is counted as 0.5 player for each team. Players may be lost to/ acquired by a team pre-season if he is traded, lost or signed through free agency, retires, is released, or is otherwise unavailable (e.g., in jail). It is not uncommon for a team to trade a good player to a more successful team mid-season if that player would be a free agent at the end of the season, especially if the team sending the star to another team has little chance of reaching the playoffs that year. 